Review

\title{
Amalgamation of Customer Relationship Management and Data Analytics in Different Business Sectors-A Systematic Literature Review
}

\author{
Lewlisa Saha $^{1}\left(\mathbb{D}\right.$, Hrudaya Kumar Tripathy ${ }^{1}$, Soumya Ranjan Nayak ${ }^{2} \mathbb{D}$, Akash Kumar Bhoi ${ }^{3,4, * \mathbb{D}}$ \\ and Paolo Barsocchi $4, *$ (iD
}

check for updates

Citation: Saha, L.; Tripathy, H.K.; Nayak, S.R.; Bhoi, A.K.; Barsocchi, P. Amalgamation of Customer Relationship Management and Data Analytics in Different Business Sectors-A Systematic Literature Review. Sustainability 2021, 13, 5279. https://doi.org/10.3390/su13095279

Academic Editors: Ricardo Chalmeta Rosaleñ and Patricia Martínez García de Leaniz

Received: 17 March 2021

Accepted: 3 May 2021

Published: 9 May 2021

Publisher's Note: MDPI stays neutral with regard to jurisdictional claims in published maps and institutional affiliations.

Copyright: (c) 2021 by the authors. Licensee MDPI, Basel, Switzerland. This article is an open access article distributed under the terms and conditions of the Creative Commons Attribution (CC BY) license (https:// creativecommons.org/licenses/by/ $4.0 /)$.
1 School of Computer Engineering, Kalinga Institute of Industrial Technology, Bhubaneswar 751024, India; 1781026@kiit.ac.in (L.S.); hktripathyfcs@kiit.ac.in (H.K.T.)

2 Amity School of Engineering and Technology, Amity University Uttar Pradesh, Noida 201301, India; srnayak@amity.edu

3 Department of Electrical and Electronics Engineering, Sikkim Manipal Institute of Technology, Sikkim Manipal University, Majitar 737136, India

4 Institute of Information Science and Technologies, National Research Council, 56124 Pisa, Italy

* Correspondence: akash.b@smit.smu.edu.in (A.K.B.); paolo.barsocchi@isti.cnr.it (P.B.)

\begin{abstract}
Customization of products or services is a strategy that the business sector has embraced to build a better relationship with the customers to cater to their individual needs and thus providing them a fulfilling experience. This whole process is known as customer relationship management (CRM). In this context, we extensively surveyed 138 papers published between 1996 and 2021 in the area of analytical CRM. Although this study consisted of papers from different business sectors, a fair share of focus was directed to the telecommunication industry and generalized CRM techniques usages. Different science and engineering-based data repositories were studied to ascertain significant studies published in scientific journals, conferences, and articles. The research works on CRM were considered and separated into IT and non-IT-based techniques to study the methods used in different business sectors. The main target behind implementing CRM is for the better revenue growth of the company. Different IT and non-IT-based techniques are used in the analytical CRM area to achieve this target, and researchers have been actively involved in this domain. The purpose of the research was to show the impact of IT-based techniques in the business world. A detailed future course of research in this area was discussed.
\end{abstract}

Keywords: customer relationship management; analytical CRM; telecommunication industry; data analytics

\section{Introduction}

These days CRM is the center of attraction of every other scholar and expert. As each day passes by, many companies are adopting the concept of CRM in their business to stay updated with the customer-oriented market. It is gradually sinking in the desperate need of exhaustively detailed familiarity of their customers' behavior to strengthen their bond with their customers. The evolution of highly efficient algorithms and platforms has altered the way of connecting with customers, leading to a better situation with the marketing, sales, and customer service functions in organizations. From a professional's perspective, CRM serves to grasp a full insight into one's customers' needs and desires and design convenient platforms for the customers to improve their relationship with the companies. This paper presents a detailed overview of customer relationship management's different aspects and the analytical aspect of it in different business organizations. Every business group's main target is to emerge an abiding relationship with its customers to cultivate its balance in today's flourishing market. The customers nowadays anticipate the best services 
and products and want a personalized service in which they expect to get precisely what they call for and also at a quick pace.

Marketing scholars are improving their perception concerning the importance and method of reciprocal communication between clients and retailers by gaining knowledge about the essence and extension of CRM. Intellectuals involved with multiple marketing branches are also committed to contemplating and examining the abstract infrastructure of managing the connection with the customers. They are intrigued by the methods used for classifying and selecting the customers; personalized connection with every customer; primary account management and clientele's business progress; density marketing, loyalty project, cross-selling and up-selling events, and different forms of collaborating with customers. It also covers co-branding, joint-marketing, co-development, and alternative forms of crucial alliances. Even though the current market is all about gaining and retaining customers, not all customers are equally important for a particular organization. That is why choosing the right customer is essential for future customer retention purposes. Every business is different; hence their targeted group of customers is also different. Therefore, segmentation of the customer type is necessary. Acquisition of customers is the first step of a customer life cycle, which is required for a long-term relationship between the customers and the organization. With time the business focus has drifted from transactional to relationship marketing, and the customers are no longer just a commercial audience but business associates. The involvement of technology in the management has increased, and so has the value of information over the years due to the need to personalize the market approach. Some of the areas where CRM strategy is being used are hotel industry, banking and insurance sectors, healthcare, higher education, agriculture, and so on.

One of the most popular business-sector deals with the most diverse group of customers is the telecommunication industry. In this day and age, where people, irrespective of their age, gender identity, profession, and location, use some communication medium, the telecom sector probably has the most requirement to study their customers' needs. Designing the service according to the customers' needs helps any business earn customer satisfaction and loyalty. Currently, the mature telecom market needs to properly understand customers' needs so that they can retain the existing customer by gaining their loyalty. Initially, when the telecommunication industry was new in the business scenario, the market was predominantly young, and new customers' incoming was also very high. With time the market has matured to a level where the competition among service providers is extremely high. As of March 2019 [1], the overall teledensity of the Indian population has risen to $90.1 \%$. As the number of new incoming customers reduces with time, the need to retain the existing customer has increased over the years. The teledensity of urban India as of March 2019 was $159.66 \%$, and that of rural India was $57.5 \%$. This shows the vast difference in the people's socio-economic status depending on the place they belong. For example, the metro city teledensity of Delhi was $238.57 \%$, Kolkata was $165.51 \%$, and Mumbai was $165.62 \%$, while teledensity of the state of Bihar was $59.95 \%$, Assam was $68.81 \%$, and so on. Therefore, place plays a huge role in defining the needs and requirements of the customers. This condition urges us to take the next step in customer relationship management, which is customer segmentation. Every customer out there may not be the ideal target customer for that particular business. A company needs to understand whether investing in a certain customer is worth it or not. If a certain customer is going to churn in the end, it would not be ideal for a company to invest in them, and hence comes the crucial step of customer churn detection.

The Indian telecommunication industry is mostly based on customers' behavioral data rather than the customer demographic data, which also plays a vital role in this. Study [1] suggested that $96 \%$ of Indian subscribers are constantly changing service providers searching for a better deal. Since it is much costlier to get a new customer than trying to keep an old one, the Indian telecommunication industry is very interested in bringing down the churn rate, which leaves us with a huge opportunity to explore the area. A customer's churn can be of two types: voluntary and involuntary. Involuntary churn can be due to 
reasons such as reallocation of the customer to a different place, death, and so on. These types of churns are excluded from the churn prediction analysis.

The remaining paper's organization is as follows: Section 2 provides a brief idea about the theoretical foundation of CRM and CRM analytics. Section 3 describes the review methodology. The distribution of the articles reviewed is presented in Section 4. Section 5 discusses the referred articles. Section 6 presents the discussion and the future scope of the review. Section 7 concludes the paper.

\section{Theoretical Foundation}

\subsection{Customer Relationship Management}

CRM is a business policy that has existed since the very concept of business started. It is a concept and strategy used to build a relationship with the customers, which helps the companies increase revenue, customer value, and service quality by understanding and satisfying every customer's needs. The concept of CRM itself is old, but due to the continuous increase in the market demand, the need to customize every product or service offered by a company has become a basic necessity. As stated by Chen and Popovich [2], CRM links the front- and back-office functions with the customers. CRM is a combination of many different customer-focused management approaches, which helps build a long-term relationship with the customers.

CRM system helps many business functionalities such as data warehousing, sales force automation, data mining, decision support, and reporting tools. As shown in Figure 1, there are mainly three types of CRM: operational, analytical, and collaborative systems. The operational CRM system uses automation and increased efficiency. The analytical CRM system is used to analyze customer data, and the collaborative CRM system is used to manage and integrate communication channels and customer interaction touchpoints.

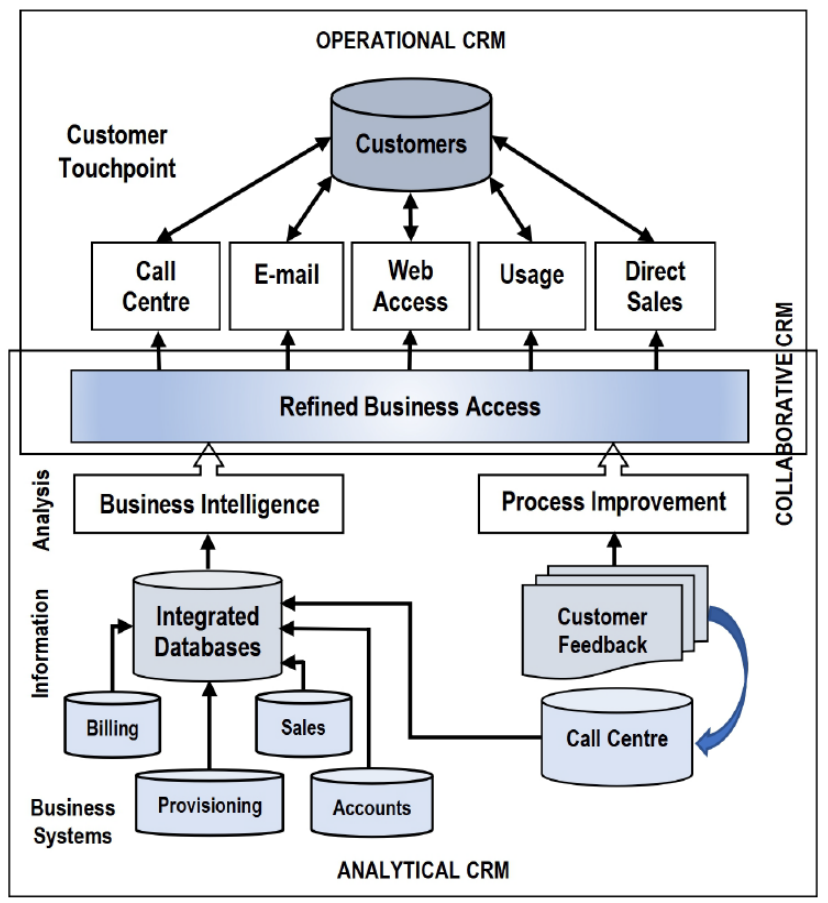

Figure 1. The interrelated CRM forms and processes.

Successful customer relationship management consisting of both front- and back-office applications is mainly managed by technology by analyzing the data. The front office maintains the continuous flow of information with the customers, and the back office analyzes these. As stated by Renartz et al. [3], the key theoretical foundation of CRM research is the literature on relationship marketing. According to the authors, the first 
aspect is building and nurturing the relationship with the current customers. The second aspect is acknowledging that the relationships evolve with phases by the CRM process. Thirdly, the evolution of relationships impacts the organization, and the firms are supposed to handle the interaction and the relationship with their customers differently at each stage, and for the fourth aspect, the non-homogeneous distribution of the relationship value to the firm.

\subsubsection{Customer Life Cycle}

According to Krishna and Ravi [4], there are three phases in the customer's life-cycle model, which includes, acquiring new customers, enhancing the profitability of existing customers, and retaining profitable customers, whereas Kuruganthi and Basu [5] in their work showed a customer's life-cycle model with four phases to it, including, acquiring the right customer, enhancing usage from existing customers, selling more products and services to existing customers, and retaining the right customer.

As shown in Figure 2, in the first stage, new customers are acquired through proper customer segmentation following target marketing. Advertising products do direct or target marketing to a specific group of customers. Then, in the second stage, different CRM techniques enhance customer usability and increase profit. The third stage manages the existing customers by selling more products or services to their customers, which ultimately leads to higher profit. In the fourth stage, a company retains the right customer who helps gain more benefits. This can be done by determining the customer churn rate and performing some sentiment analysis.

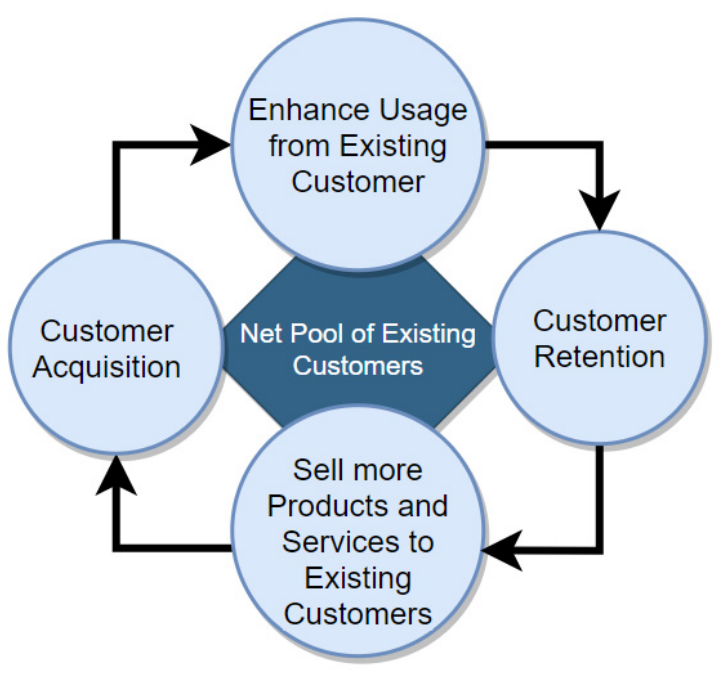

Figure 2. Customer's life cycle.

\subsubsection{Customer Acquisition}

According to Kuruganthi and Basu [5], customer acquisition mainly involves three steps, as shown in Figure 3. Firstly, to decide whom to target as your customer to offer the product or service. Secondly, to determine the type of product or service to provide a particular customer and, finally, provide those products and services to the customers. The first step is decided by customer segmentation, which breaks down the customers into different groups, which leads us to the second step, where depending on the segmented groups, the products and services are decided. Lastly, various distribution methods are agreed to keep in mind the criteria of the derived groups. 


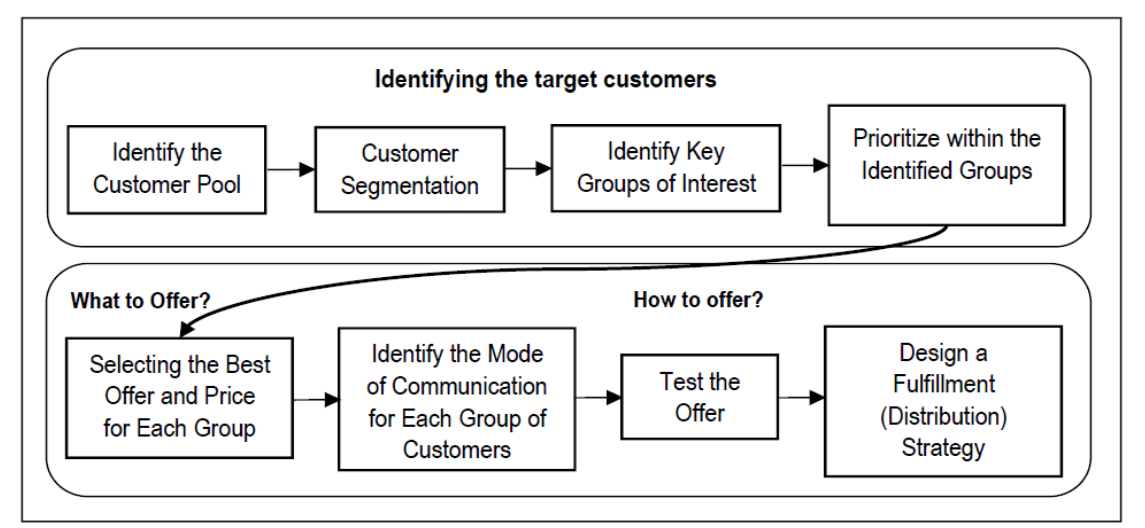

Figure 3. Steps of customer acquisition.

\subsection{CRM Analytics}

According to Reinartz et al. [3], information technology is a critical moderator of a firm's economic performance. CRM analytics is the implementation of different analytical techniques in CRM for better customer relationship maintenance. The possibilities of IT-based CRM techniques go to a considerable extent, from identifying the customers need to improve the organization's performance in the market. The full advantages of implementing IT in CRM enable companies to identify customer patterns, understand their behavior, perform predictive analysis, customize products and services, etc. With all the information from the customer interaction, the company can get an overall view of the customer's needs and predict what kind of product and service to offer. Hence effective management of the information is a vital part of CRM, and data warehouses, enterprise resource planning (ERP) systems, and the Internet are central infrastructures to CRM applications. These days businesses are mostly based on their data analysis capabilities. According to Anshari et al. [6], only 8\% of businesspersons have all-inclusive and productive solutions in collecting and analyzing these data. According to the data analytics survey in an organization conducted by Evans Data Corporation (Figure 4), departments that deal with customers such as marketing, sales, and customer service are the predominant users for $38.2 \%$ of all big data and advanced analytical applications. Among these, the marketing department (14.4\%), IT (13.3\%), and research for $13 \%$ are the most frequent users.

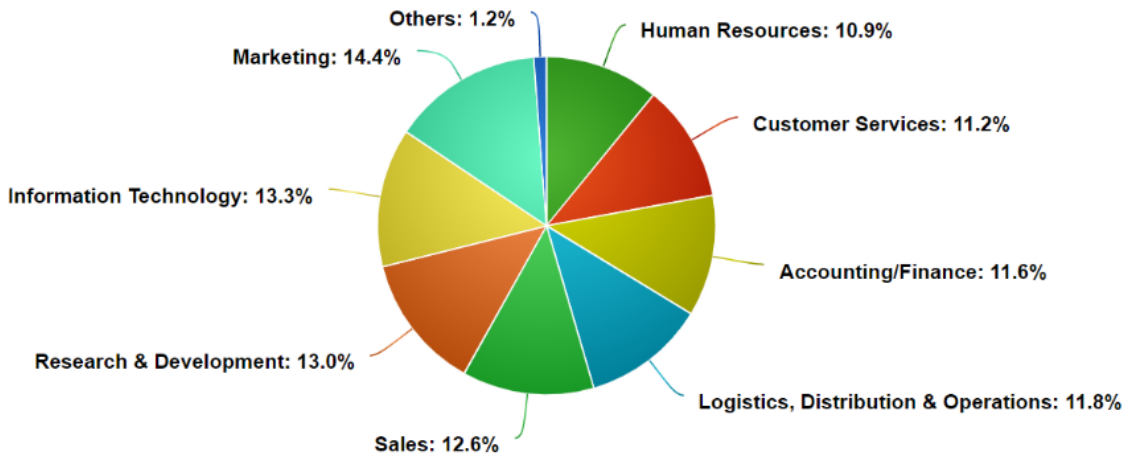

Figure 4. Big data analytics usage in organization. Sources: Evans Data Corporation.

In the last two decades, the amount of data has grown excessively due to the IT industry's growth. Alongside there has been considerable progress in data analysis. Different new approaches and techniques have been introduced to collect the information from the collected data. The relevant information obtained by applying the analytic data techniques is already hidden in the gathered raw data. These analytic data techniques can be used in many different areas. Data analysis deals with both structured and unstructured forms of data and in vast quantities, which would be very hard to work on using conventional 
database management systems. Big data open a massive collection of applications and opportunities in multiple vertical sectors including, but not limited to, telecommunication, retail business, insurance, and financial services, healthcare, television and media, utility services, medicine and pharmaceutical, governance, and national security.

\section{Review of Different Methodology}

\subsection{Techniques Referred to in the Review}

As Krishna and Ravi [4], in their survey have reviewed articles using EC techniques, therefore, in our review, we broadened our research area by including both IT and non-ITbased methods. In Table 1, a brief overview of the IT-based techniques used in the reviewed articles is discussed, along with their advantages and disadvantages.

\subsection{Flowchart of the Review Methodology}

In this section, a flowchart of the review process is shown in Figure 5, which shows the step-by-step process that was followed to perform the survey on the different aspects of CRM and its application from a different business perspective. Both online and offline data repositories were referred to for this survey, and based on preferences, the papers were sectioned for further studies.

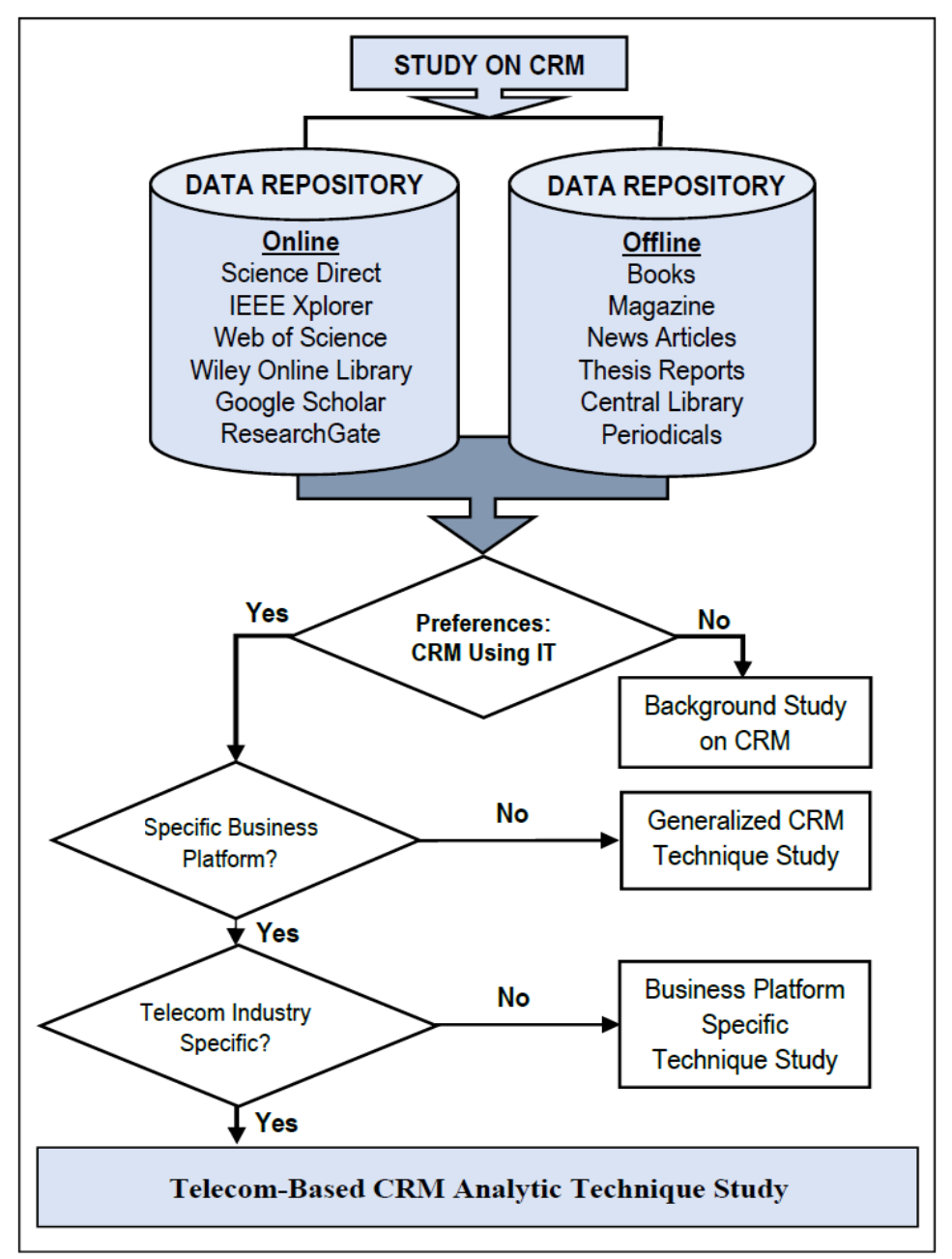

Figure 5. Flowchart of the review methodology. 
Table 1. IT-based techniques.

\begin{tabular}{|c|c|c|c|}
\hline $\begin{array}{c}\text { IT-Based } \\
\text { Techniques Used }\end{array}$ & Basic Idea & Advantages & Disadvantages \\
\hline $\begin{array}{l}\text { Association Rule } \\
\text { Mining }\end{array}$ & $\begin{array}{l}\text { Association Rule mining is a rule-based } \\
\text { data-mining method used mainly for the purpose } \\
\text { of frequent pattern recognition from any dataset or } \\
\text { data repository. Rule mining uses the criteria } \\
\text { support and confidence to identify the most } \\
\text { important pattern. } \\
\text { Types of association rule mining used in the paper: } \\
\text { - } \quad \text { A priori; } \\
\text { - } \quad \text { FP growth. }\end{array}$ & 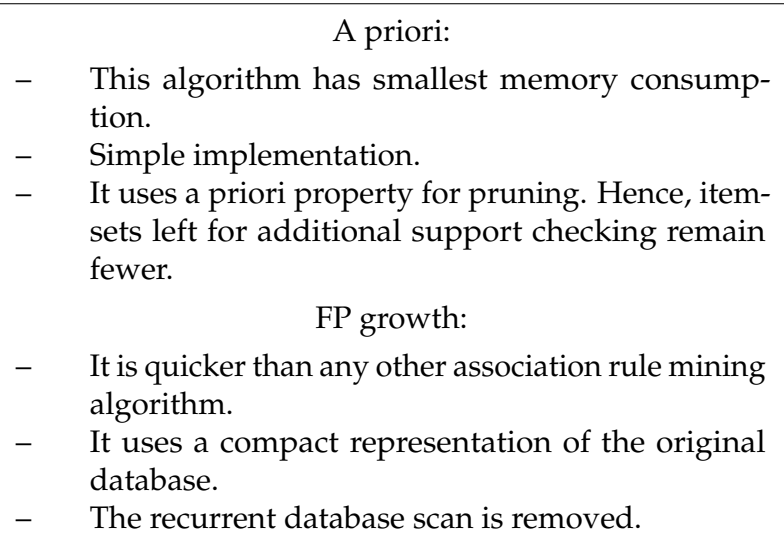 & $\begin{array}{l}\text { A priori: } \\
\text { - } \quad \text { It needs many examinations of database. } \\
\text { - } \quad \text { It permits only a single minimum support threshold. } \\
\text { - } \quad \text { It is suitable only for a smaller database. } \\
\text { - } \quad \text { It clarifies only the presence or absence of an element } \\
\text { in the database. } \\
\text { FP growth: } \\
\text { - } \quad \text { The memory usage is higher. } \\
-\quad \text { It cannot be accepted for interactive mining and } \\
\text { incremental mining. } \\
\text { The resultant FP Tree is not exclusive to a similar } \\
\text { logical database. }\end{array}$ \\
\hline Classification & $\begin{array}{l}\text { Classification is a data-mining technique in which } \\
\text { itemsets are assigned to target classes or levels. The } \\
\text { goal of this technique is to predict the right class for } \\
\text { a particular data item correctly. It has two steps: } \\
\text { 1. Training; } \\
\text { 2. Testing. } \\
\quad \text { Types of classification used in the paper: } \\
\text { - } \quad \text { k-nearest neighbor; } \\
\text { - } \quad \text { Decision tree; } \\
\text { - } \quad \text { Artificial neural network; } \\
\text { - } \quad \text { Support vector machine; } \\
\text { - } \quad \text { Bayesian classifier. }\end{array}$ & 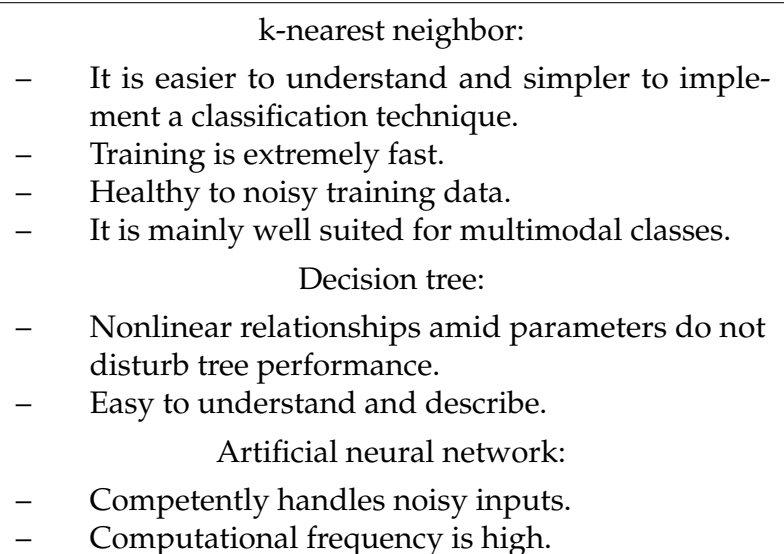 & $\begin{array}{l}\text { k-nearest neighbor: } \\
\text { - } \quad \text { It is delicate for the local structure of the data. } \\
-\quad \text { Memory restriction. } \\
\text { - } \quad \begin{array}{l}\text { Being supervised learning lazy algorithm, i.e., runs } \\
\text { leisurely. }\end{array} \\
\text { - } \quad \text { Complexity. } \\
-\quad \text { Likelihood of repetition with the same sub-tree on } \\
\text { diverse paths. } \\
\quad \text { Artificial neural network: } \\
-\quad \text { It is semantically poor. } \\
\text { - Harder to choose the type of network architecture. }\end{array}$ \\
\hline
\end{tabular}


Table 1. Cont.

\begin{tabular}{|c|c|c|c|}
\hline $\begin{array}{c}\text { IT-Based } \\
\text { Techniques Used }\end{array}$ & Basic Idea & Advantages & Disadvantages \\
\hline Classification & & \begin{tabular}{ll} 
& \multicolumn{1}{c}{ Support vector machine: } \\
$-\quad$ & Contributes very precise classifiers. \\
- & Low overfitting, robust to noise. \\
- & $\begin{array}{l}\text { Particularly prevalent in text classification prob- } \\
\text { lems where extremely high-dimensional spaces } \\
\text { are the standard. }\end{array}$ \\
$-\quad$ & \multicolumn{1}{c}{ Memory-intensive. } \\
Bayesian classifier: \\
$-\quad$ To improve the classification performance by elim- \\
inating the unrelated features. \\
$-\quad$ Better performance. \\
Less computational time.
\end{tabular} & $\begin{array}{l}\text { Support vector machine: } \\
\text { - } \quad \text { SVM is a binary classifier. To do a multi-class clas- } \\
\text { sification, pair-wise classifications can be used (one } \\
\text { class against all others, for all classes). } \\
\text { - Computationally costly, thus runs slow. } \\
\text { Bayesian classifier: } \\
\text { - } \quad \text { Information theoretically infeasible. } \\
\text { - Computationally infeasible. }\end{array}$ \\
\hline Clustering & $\begin{array}{l}\text { Clustering is an unsupervised data-mining } \\
\text { technique that divides a huge dataset into smaller } \\
\text { groups by increasing inter-group similarity and } \\
\text { reducing the intragroup similarity. }\end{array}$ & 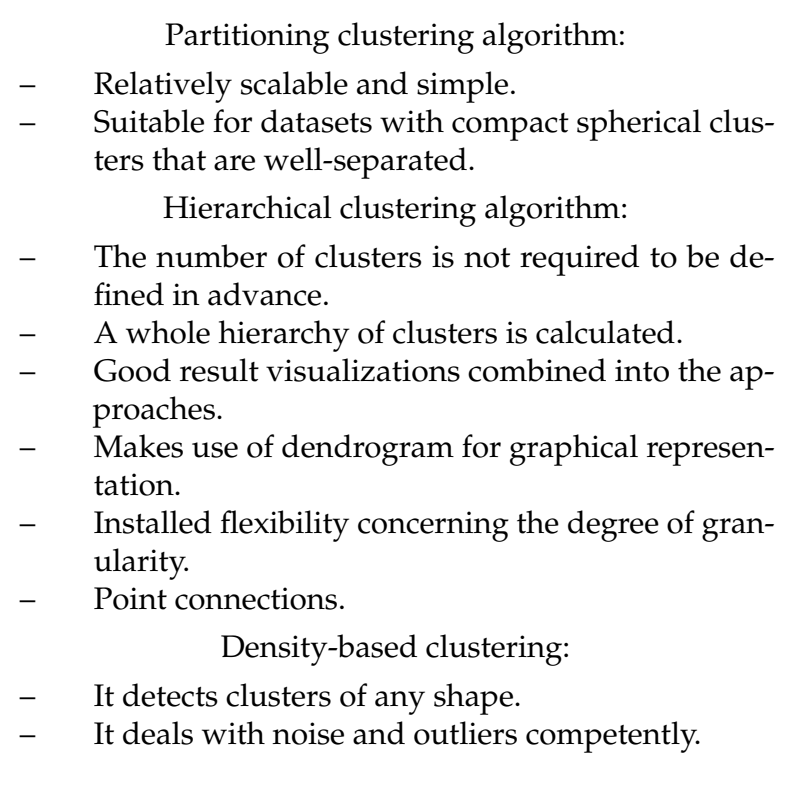 & 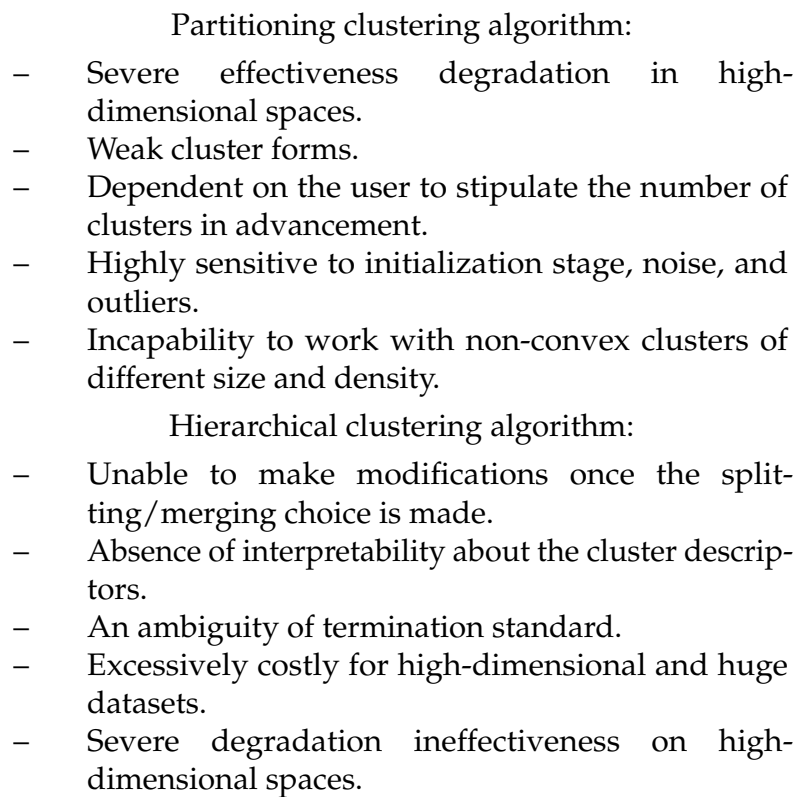 \\
\hline
\end{tabular}


Table 1. Cont.

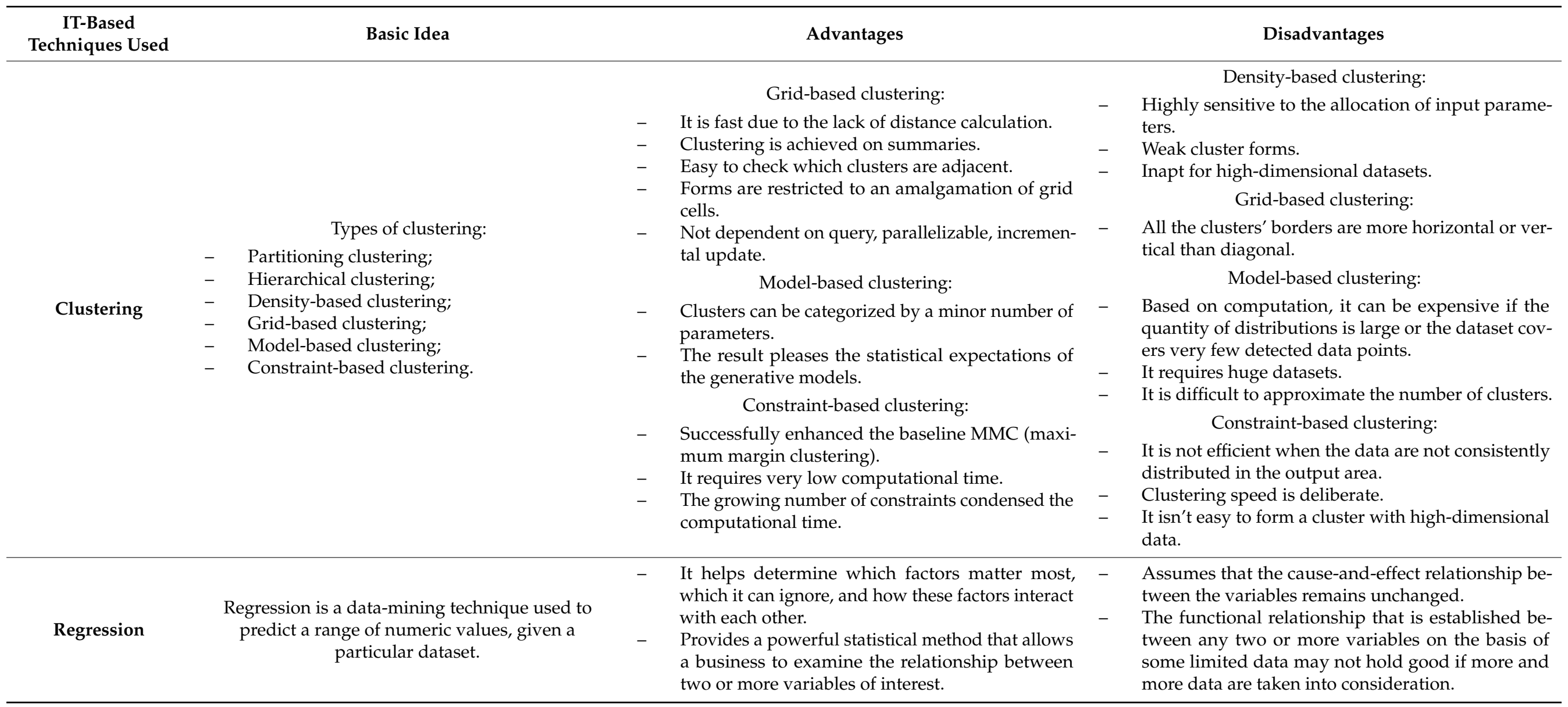


Table 1. Cont.

\begin{tabular}{|c|c|c|c|}
\hline $\begin{array}{c}\text { IT-Based } \\
\text { Techniques Used }\end{array}$ & Basic Idea & Advantages & Disadvantages \\
\hline Factor Analysis & $\begin{array}{l}\text { Factor analysis is a technique that is used to reduce } \\
\text { a large number of variables into fewer numbers of } \\
\text { factors. This technique extracts maximum common } \\
\text { variance from all variables and puts them into a } \\
\text { common score. As an index of all variables, we can } \\
\text { use this score for further analysis. Several methods } \\
\text { are available, but principal component analysis is } \\
\text { used most commonly. }\end{array}$ & $\begin{array}{l}\text { - } \quad \text { High data reduction and aggregation. } \\
\text { - } \quad \text { Deals with measurement errors and others issues } \\
\text { regarding it. } \\
\text { - } \quad \text { Helps with exploratory analysis or confirmatory } \\
\text { analysis. }\end{array}$ & $\begin{array}{l}\text { - } \quad \text { Final factors are difficult to interpret. } \\
\text { - } \quad \text { Based on the data, the aggregation and weight vary. }\end{array}$ \\
\hline $\begin{array}{l}\text { Structural } \\
\text { Equation } \\
\text { Modeling }\end{array}$ & $\begin{array}{l}\text { Structural equation modeling is a multivariate } \\
\text { statistical analysis that combines factor analysis and } \\
\text { multiple regression analysis. This technique is used } \\
\text { to analyze the structural relationship between } \\
\text { measured variables and latent constructs using two } \\
\text { types of variables: endogenous and exogenous. }\end{array}$ & $\begin{array}{l}\text { - Allows using several indicator variables per con- } \\
\text { struct simultaneously, which leads to more valid } \\
\text { conclusions on the construct level. } \\
\text { Takes measurement error into consideration by } \\
\text { openly including measurement error variables } \\
\text { that resemble the measurement error portions of } \\
\text { observed variables. } \\
\text { Allows to model and test complex patterns of re- } \\
\text { lationships, including a multitude of hypotheses } \\
\text { simultaneously. } \\
\text { It allows to test complex models for their com- } \\
\text { patibility with the data in their entirety and test } \\
\text { specific assumptions about parameters for their } \\
\text { compatibility with the data. }\end{array}$ & $\begin{array}{l}\text { - A multitude of parameters corresponding to vari- } \\
\text { ous hypotheses is estimated simultaneously, only if } \\
\text { the empirical data provide enough information to } \\
\text { estimate all these parameters. } \\
\text { - Simultaneously including a multitude of relation- } \\
\text { ships is computationally intensive and can lead to } \\
\text { estimation problems. }\end{array}$ \\
\hline Statistical Analysis & $\begin{array}{l}\text { Statistical analysis is used in business intelligence } \\
\text { (BI) to collect and analyze every data sample in a } \\
\text { group of items to draw samples. There are five } \\
\text { steps for statistical analysis: } \\
\text { - } \quad \text { Describe the nature of the data to be analyzed. } \\
\text { - Explore the relation of the data to the underly- } \\
\text { ing population. } \\
\text { - Create a model to summarize understanding } \\
\text { of how the data relate to the underlying popu- } \\
\text { lation. } \\
\text { - Prove (or disprove) the validity of the model. } \\
\text { Employ predictive analytics to run scenarios } \\
\text { that will help guide future actions. }\end{array}$ & $\begin{array}{ll}\text { - } & \text { Helps with sampling errors. } \\
\text { - } & \text { Provides simple answers to complex questions. } \\
\text { - } & \text { It helps in making accurate predictions. }\end{array}$ & $\begin{array}{l}\text { - If researchers collect data using faulty or biased pro- } \\
\text { cedures, the resulting statistical analysis will be mis- } \\
\text { leading. } \\
\text { - A tendency to jump to baseless assumptions about } \\
\text { causal relationships. } \\
\text { - If researchers do not measure the right thing, the } \\
\text { analysis will fail. }\end{array}$ \\
\hline
\end{tabular}


Table 1. Cont.

\begin{tabular}{|c|c|c|c|}
\hline $\begin{array}{c}\text { IT-Based } \\
\text { Techniques Used }\end{array}$ & Basic Idea & Advantages & Disadvantages \\
\hline Hypothesis Testing & $\begin{array}{l}\text { Hypothesis testing is used in statistics to test the } \\
\text { result of any experiments for its feasibility. Here, } \\
\text { the results are tested for their validity by checking } \\
\text { whether the experiment is repeatable or obtained by } \\
\text { chance. If the experiment is not repeatable and the } \\
\text { result was obtained by chance, it is of little to no } \\
\text { use. }\end{array}$ & $\begin{array}{l}\text { - It forces us to think deeply about the possible out- } \\
\text { comes of a study. } \\
\text { - } \\
\text { Restating questions as hypotheses involves prior } \\
\text { evidence or theoretical argument. } \\
\text { - It helps the researcher to see whether or not they } \\
\text { are investigating a relationship. }\end{array}$ & $\begin{array}{ll}- & \text { Dependent on concentrations tested. } \\
\text { - } & \text { Inability to calculate confidence intervals. }\end{array}$ \\
\hline Topic Modeling & $\begin{array}{l}\text { Topic modeling is an unsupervised machine } \\
\text { learning technique whose main purpose is scanning } \\
\text { a set of documents, spotting word and phrase } \\
\text { patterns within them, and automatically clustering } \\
\text { word groups and similar expressions that best } \\
\text { characterize a set of documents. }\end{array}$ & $\begin{array}{l}\text { - } \quad \text { Each document is assigned a probability of belong- } \\
\text { ing to a latent theme or "topic." } \\
\text { - } \quad \text { Employs more sophisticated iterative Bayesian } \\
\text { techniques to determine each document's prob- } \\
\text { ability associated with a given theme or topic. }\end{array}$ & $\begin{array}{l}\text { - Does not produce highly nuanced classification of } \\
\text { texts. } \\
\text { - It can easily be abused if it is wrongly understood } \\
\text { as an objective representation of a text's meaning. }\end{array}$ \\
\hline $\begin{array}{c}\text { Data Envelopment } \\
\text { Analysis }\end{array}$ & $\begin{array}{l}\text { Data envelopment analysis (DEA) is a linear } \\
\text { programming methodology to measure the } \\
\text { efficiency of multiple decision-making units } \\
\text { (DMUs) when the production process presents a } \\
\text { structure of multiple inputs and outputs. }\end{array}$ & $\begin{array}{l}\text { - No need to explicitly specify a mathematical form } \\
\text { for the production function. } \\
\text { - } \quad \text { It was proven to be useful in uncovering relation- } \\
\text { ships that remain hidden for other methodologies. } \\
\text { - } \quad \text { Capable of handling multiple inputs and outputs. } \\
\text { - } \quad \text { Capable of being used with any input-output mea- } \\
\text { surement. } \\
\text { - The sources of inefficiency can be analyzed and } \\
\text { quantified for every evaluated unit. }\end{array}$ & $\begin{array}{l}\text { - Results are sensitive to the selection of inputs and } \\
\text { outputs. } \\
\text { - The best specification cannot be tested. }\end{array}$ \\
\hline
\end{tabular}




\section{Distribution of the Articles Reviewed}

For this survey, a total of 138 papers were considered. Five papers mainly concentrate on discussing the background of CRM and its working in a very generalized perspective; 41 articles are studies on techniques used in different aspects of CRM. There are 91 papers that are business-specific CRM applications focusing on the healthcare system, hotel management, hospitality management, banking, retail industry, and so on and among which 50 research papers focus specifically on the CRM application in the telecommunication industry.

Figure 6 shows a year-wise citation representation of the articles reviewed, and Figure 7 shows the number of publications each year.

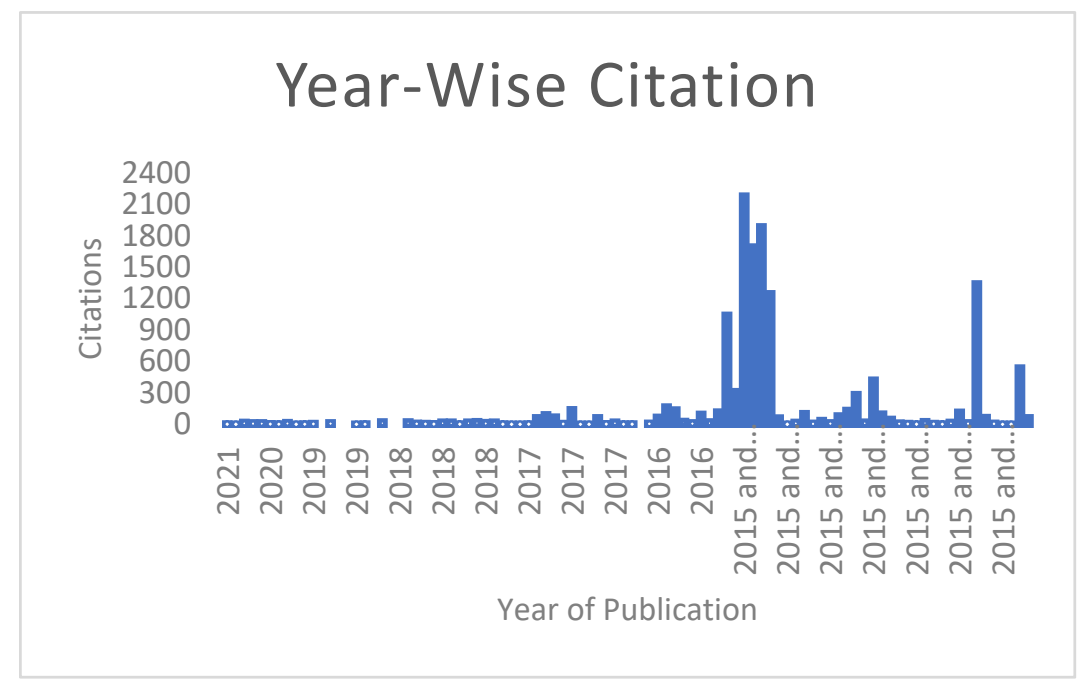

Figure 6. Citation-based representation.

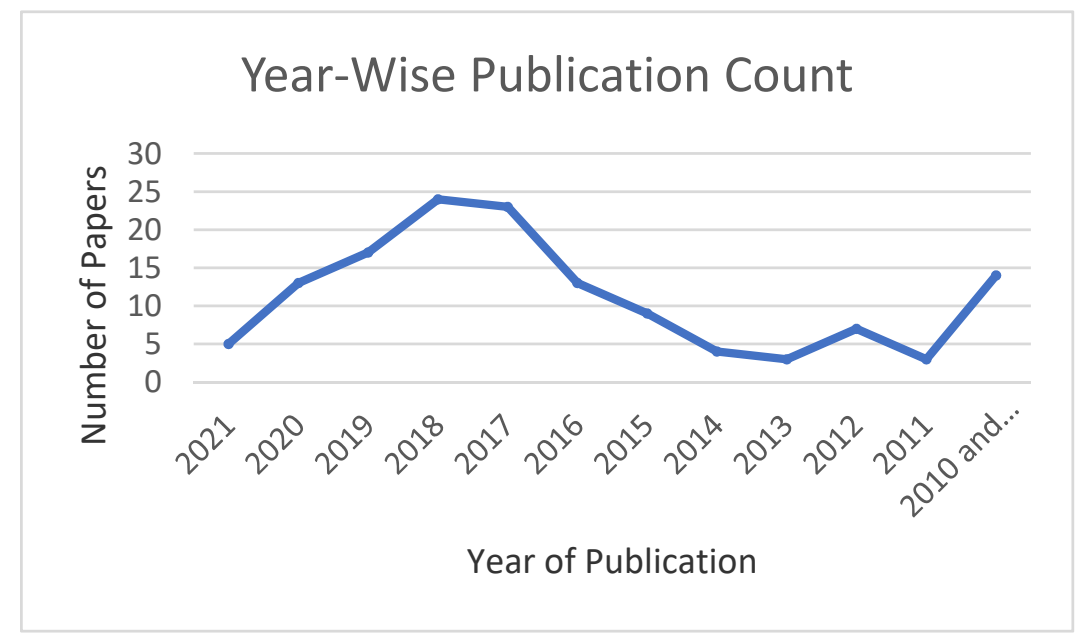

Figure 7. Publication count representation.

A business-specific description is presented in Figure 8, which indicates the number of articles from each area, and a technique-wise representation is given in Figure 9. 


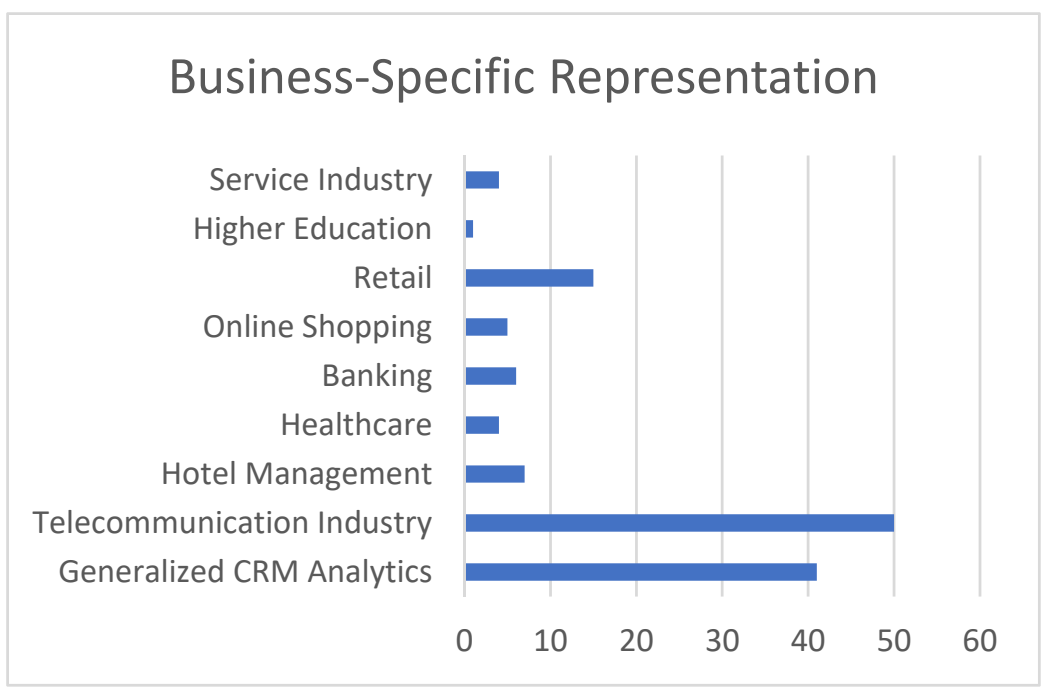

Figure 8. Industry-specific representation.

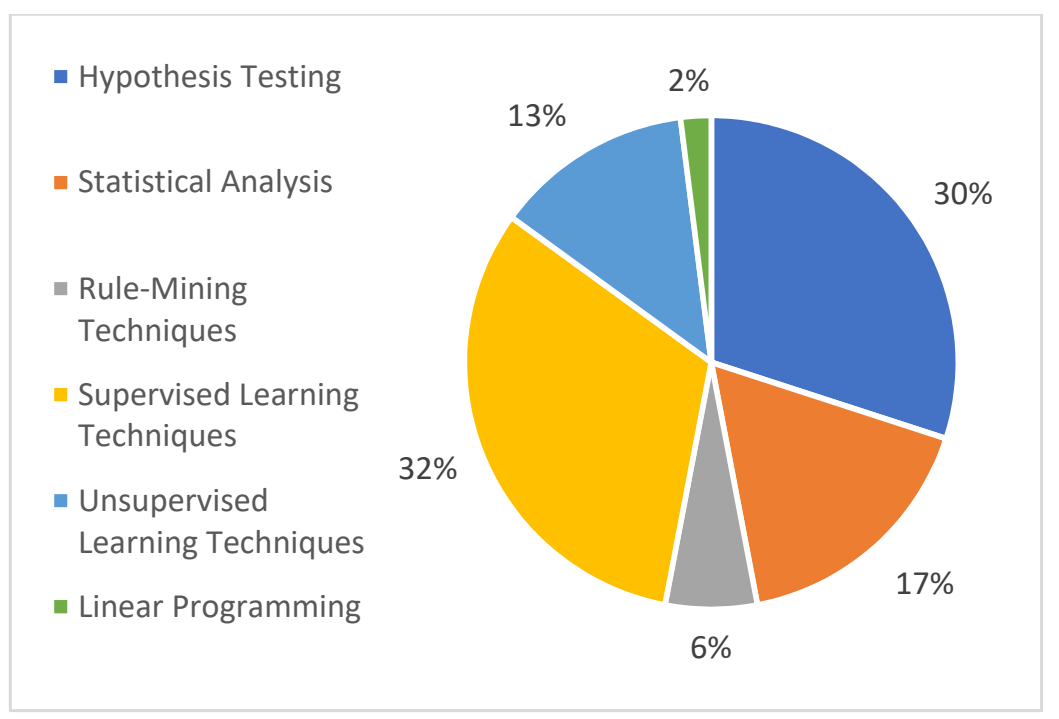

Figure 9. Technique-wise representation.

Figure 10 represents the areas where the techniques have been applied, and Figure 11 shows the number of papers that referred to different aspects of CRM in the telecom industry.

Finally, Figure 12 shows the accuracy obtained by different authors using supervised learning techniques (decision tree, Naïve Bayes, support vector machine, neural network, regression analysis). 


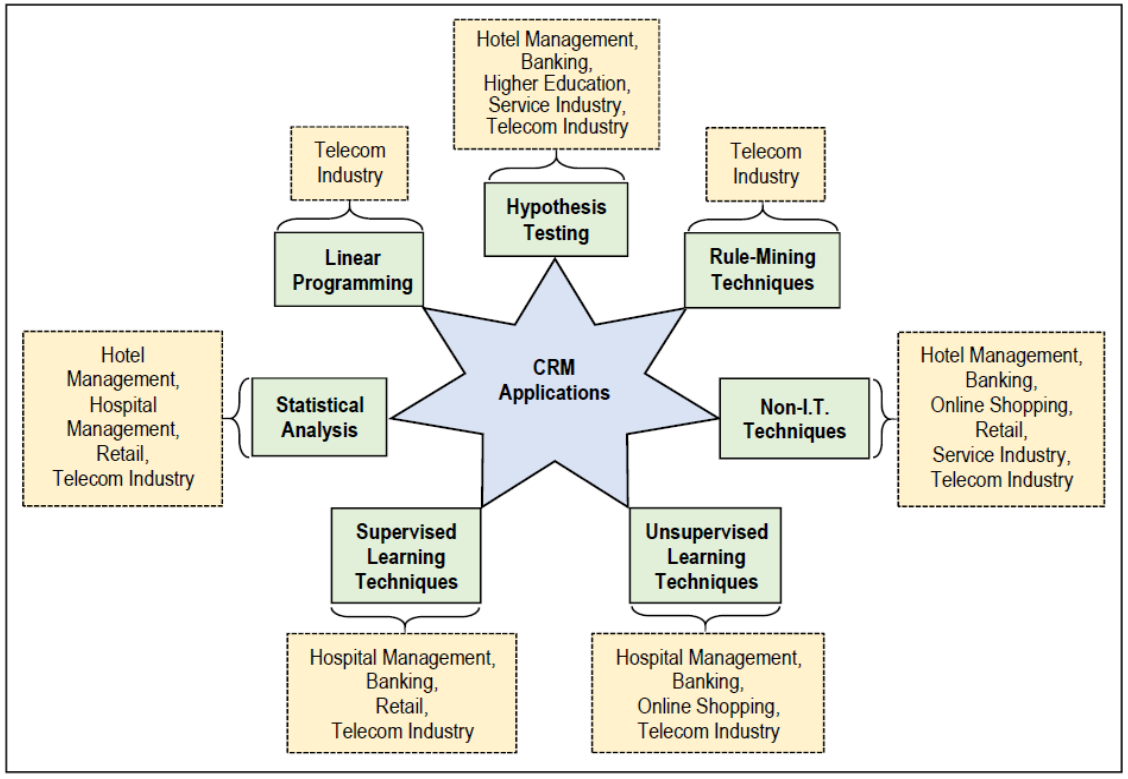

Figure 10. Different applications of CRM analytical techniques.

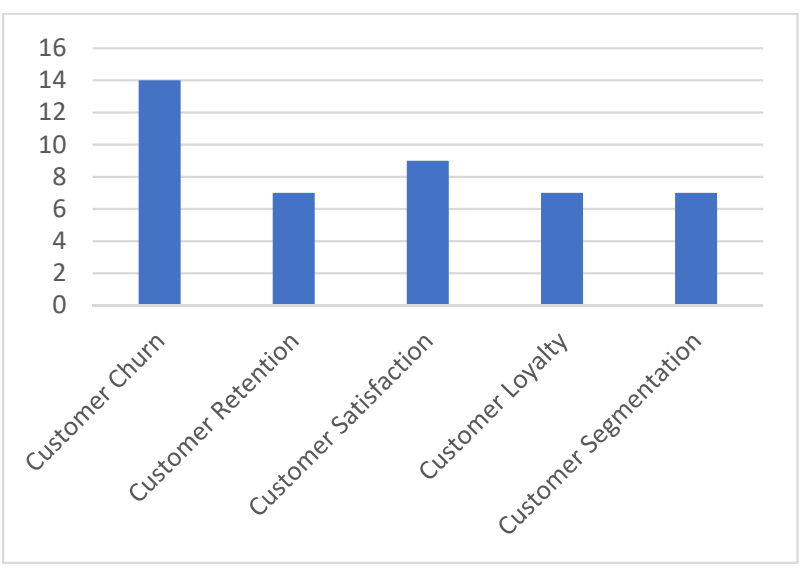

Figure 11. CRM technique-wise representation.

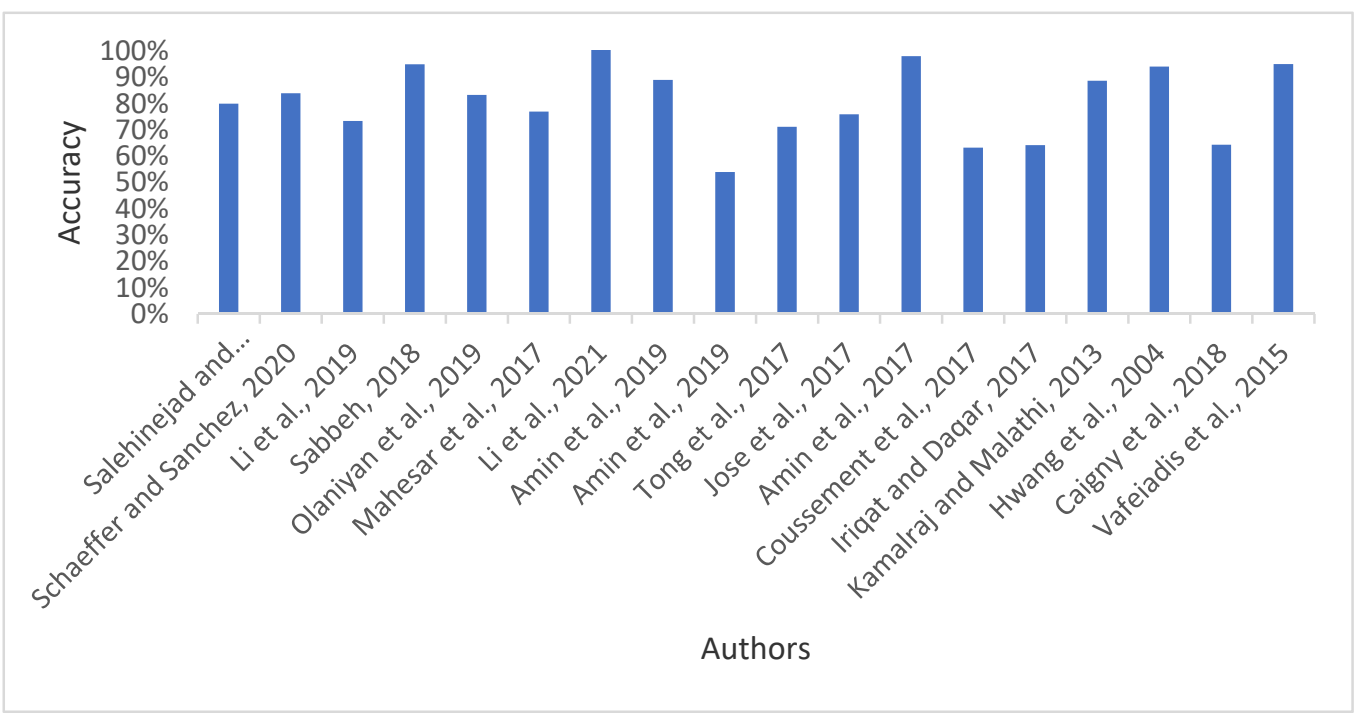

Figure 12. Accuracy representation of the supervised learning techniques. 


\section{Review of the Related Works}

\subsection{Background Study on CRM}

Customer relationship management (CRM) is more than just a buzzword going around in the business world. It is a process of building a proper relationship between the customers and the company so that both sides can gain out of it. An enormous amount of research work has been done and still going on implementing CRM in the business sectors properly. However, for that, we need to understand the working and details behind that concept of CRM. Rababah et al. [7] conducted an extensive study on the CRM processes concentrating on different viewpoints, types, and levels of CRM processes. Their research revealed four critical positions: customer-facing level processes, cross-functional CRM processes, customer-oriented processes, and CRM macro-level processes. According to their work, a better understanding of the different levels of CRM processes is required. To implement these processes, businesses need to grasp better process reengineering and effective management of the changes. Parvatiyar and Seth [8], in their work, ventured into the theoretical foundation of customer relationship management to study the existing literature on marketing and other areas that contribute to CRM. They proposed a process framework on CRM that is based on other process models for relationship development. Their paper also showed some of the implementation challenges that CRM faces and its potential to become a discipline of its own. In their work, Khodakarami and Chan [9], suggested that the effect of CRM on the customer knowledge formation process also includes internalization, combination, socialization, and externalization. The authors' analysis revealed an analytical CRM system actively supports the combination process. Their work showed that collaborative systems support externalization and socialization within an organization, whereas the operating system allows socialization with customers and collaborative and analytical support internalization process. Understanding the customers and maintaining the relationship between them and the company has become a common trait among the researchers. Reinartz et al. [4], in their work, concentrated on theorizing the CRM process, validating the construct, and examining the effect of CRM process implementation on the organizational performances. They used two cross-sectional studies on four different industries and three countries to answer their research question. Their first outcome was a tentatively working CRM process, and the second was a positive effect of CRM implementation on company performance. CRM, the amalgamation of people, processes, and technology, is used to retain customers by developing their relationships. However, a successful application of the concept can be hard for many companies. Chen and Popovich [2], in their work, provided a better understanding of the reengineering of the customer-focused business process.

\subsection{CRM Analytics}

Hypotheses testing is one of the widespread techniques used in CRM analytics to validate their assumptions' feasibility. Authors have used hypotheses testing to show IT's influence on CRM based on different models and techniques. Similarly, Li et al. [10], in their study, showed that the functional benefits of CRM lead to firms' high revenue per employee and high profitability. In contrast, the strategic interests of CRM lead to firms' high customer satisfaction, high profitability, and market valuation. Their work's limitation lies in the lack of comprehensive analyses of the different types of usage and their corresponding performance effect. Nam et al. [11] also challenged the lack of proper research on business analytics (BA) by working on customer relationship management in BA using the empirical model. According to the result, data management connects IT competence and BA use, whereas customer response connects BA use and CRM performance. In another work, Dong et al. [12] used hypotheses testing as one of the first efforts to examine and explain big data analytics' effect on the market performance by using social media analytics as an instance. Here the authors described the reason behind the creation of superadditive value in social media analytics and further extended their theory by considering differences 
between different enterprises (small, medium, and large) that ultimately combine social media diversity with big data analytics.

The empirical analysis showed a positive effect on market performance when social media interacted with big data analytics. It was used by Fink et al. [13] in their paper, which aimed at connecting the gap between information technology (IT) value creation and business intelligence (BI) by developing and testing a model based on BI value creation. Nyadzayo and Khajehzadeh [14] tried to explain how the quality of CRM influences service quality, customer value, and customer satisfaction, which also helps with customer loyalty. They also took into consideration the effect of brand image on the relationship with the customer. The findings state that a better brand image indirectly helps achieve customer satisfaction and thus increases customer loyalty. Verhoef [15] used the survey to get the different impacting factors of customer retention. According to their research, aspects such as affective commitment and loyalty programs positively impact customer retention and customer share development.

Structural equation modeling (SEM) is a commonly used statistical analysis technique in CRM analytics. Mikalef et al. [16] addressed the question of "how big data can help attain a competitive advantage." The study covered the dynamic capabilities view, resourcebased view, and the link between a firm's significant data analytics capability (BDAC) and competitive performance. They proposed that BDACs empower firms to predict and adapt to the continuously changing market scenarios. Shi et al. [17] integrated the concept of bias when it comes to a customer's brand loyalty. According to the results, inertia influences a customer's brand loyalty. They also showed that deliberate inertia and cognitive lock-in have a conclusive outcome on it. In another work Benitez et al. [18], it was established that IT offers a business the flexibility of opportunity exploration, which helps exploit those opportunities by using SEM. E-CRM is vastly used in significant companies without much concern regarding the misuse of information. Pradana et al. [19] addressed the issue as mentioned above by referring to PT Garuda Indonesia, known for using e-CRM to provide better service.

According to the result, the quality of service and the behavior of the kinds of staff influence customer satisfaction. Navimipour and Soltan [20] tried to determine the most effective factors for a better performing E-CRM. They assessed the causal model and reliability and validity of the measurement model. The result of the analysis shows the effects of technology on the performance start with the infrastructure's capability, ease of use, and E-learning systems. The research also indicated the positive influence of the customer cost on customer relationship performance.

Equivalence class transformation is a depth-first search algorithm used for proper itemset mining, a significant step in association rule mining. Chen et al. [21] used the behavioral pattern of customers to define the usage characteristics and calculate customers' heterogeneity. According to their research, behavioral attributes provide a better measure for customer segmentation than demographic characteristics.

Topic modeling is an unsupervised machine learning technique used for text mining and was used by Prollochs et al. [22] in their work on strategic management. The authors' work, which necessitates a valuation of a firm's internal and external situations, extended management tools by building an automated text mining framework. They also quantified the usage of language and two scopes - risk and optimism - which divulges into a firm's strong and weak points by recognizing business units, events, and identifying processes that are prone to risk, and studying it concerning competitors or the market.

Gradient boosting machine (GBM), a broadly used machine learning technique for regression and classification problems, has a wide range of practical applications. Hu et al. [23] proposed a two-part framework: development of the downward prediction process and establishment of the methodology for identifying the cause behind the downward trend. This approach can find the silent sufferers, and these bad experiences are used to develop the framework. The marketing A/B test was used to validate the framework, and it lifted the purchase volume by $88.5 \%$. 
Clustering divides massive datasets into smaller groups where the smaller groups are known as clusters containing similar objects. This data-mining technique is very much applied to customer segmentation in CRM. In their paper, Manu [24] provided a detailed study of the different clustering techniques that are used in CRM.

Some non-IT-based techniques are used in CRM analytics for different studies. One example of such a study Krishnamoorthi et al. [25] extends an existing model to business analytics to identify elements of technological assets and their business analytics capability to grasp the mechanism of business value creation means of numerous case studies. They showed how analytical resources influence business performance by creating operational and organizational performance measures. Again, QFD (quality function development), a non-IT-based customer-oriented technique used for product design, uses a generalized customer requirement to gain maximum customer satisfaction. However, with time, the customers' needs have diversified due to their varied preferences. Luo et al. [26] proposed a QDF-based product planning approach that considers the heterogeneity of CRs by implementing consumer choice behavior analysis. The author introduced customers' purchase choice rules in the QDF-based product planning method, proposed two new QDF-based optimization models under deterministic and multinomial logit consumer choice rules, and extended these models for both continuous and discrete target values.

Few kinds of research offer a brief idea about the current work in CRM analytics and the application of IT in it. Anshari et al. [6] aimed to examine the effect of big data in CRM's scenario. The data were collected through literature review and thematic analysis from recent studies for this research. According to the survey, CRM, combined with big data, has facilitated businesses to become more dynamic in marketing strategy. Soltani and Navimipour [27] addressed the lack of comprehensive and methodic study on analyzing the techniques used to build and maintain a profitable relationship. They conducted a detailed survey on the most recent technologies used in CRM by considering five groups: knowledge management, data quality, E-CRM, data mining, and social CRM. Krishna and Ravi [3] surveyed 78 papers published throughout 1998 and 2015, which were based explicitly on evolutionary computing techniques in CRM tasks. Through their investigation, the authors showed the adaptability of EC methods in CRM when applied to the service industry. Ngai et al. [28] suggested providing a classification scheme to classify articles over 2000 and 2005, which covered 24 journals. These included categorizations based on four CRM dimensions and seven data-mining functions. Table 2 discusses the techniques and datasets used in each of the articles reviewed in this section.

Table 2. Techniques and datasets used in the articles related to CRM analytics.

\begin{tabular}{ccc}
\hline Reference & Techniques Used (IT-Based) & Dataset Used \\
\hline Li et al. [10] & Hypothesis Testing & $\begin{array}{c}\text { Harte-Hanks CI Technology Database, } \\
\text { Compustat, and ACSI as data sources. }\end{array}$ \\
\hline Mikalef et al. [16] & $\begin{array}{c}\text { Partial Least Square (PLS) Structural } \\
\text { Equation Modeling }\end{array}$ & $\begin{array}{c}\text { Real-life survey data from Norwegian } \\
\text { firms. }\end{array}$ \\
\hline Chen et al. [21] & Equivalence Class Transformation & $\begin{array}{c}\text { Application called AppData based on } \\
\text { Android mobile platform. }\end{array}$ \\
\hline Nam et al. [11] & Hypothesis Testing & Real-life survey data from firms. \\
\hline Prollochs and Feuerriegel [22] & Topic Modeling & Financial disclosure from firms. \\
\hline Dong and Yang [12] & Hypothesis Testing & Survey data from social media. \\
\hline Shi et al. [17] & Structural Equation Modeling & Survey data of smartphone consumers. \\
\hline Benitez et al. [18] & Partial Least Square Path Modeling & Real-life survey data from Spanish firms. \\
\hline Hu et al. [23] & Gradient Boosting Machine (G.B.M.) & Customer survey data. \\
\hline Pradana et al. [19] & Structural Equation Modeling & Survey data collected from PT Garuda \\
Indonesia.
\end{tabular}


Table 2. Cont.

\begin{tabular}{|c|c|c|}
\hline Reference & Techniques Used (IT-Based) & Dataset Used \\
\hline Fink et al. [13] & Hypothesis Testing & $\begin{array}{l}\text { Data collected through interviews in } \\
\text { three firms. }\end{array}$ \\
\hline Nyadzayo and Khajehzadeh [14] & Hypothesis Testing & $\begin{array}{l}\text { Customer data from three motor } \\
\text { dealership brands in South Africa. }\end{array}$ \\
\hline Navimipour and Soltani [20] & Structural Equation Modeling & $\begin{array}{c}\text { Employee data from East Azerbaijan Tax } \\
\text { Administration in Iran. }\end{array}$ \\
\hline Chopra [24] & Cluster Analysis & N. A. \\
\hline Sundararaj and Rejeesh [29] & Chi-Square Method & Social networking site. \\
\hline Salehinejad and Rahnamayan [30] & Recurrent Neural Network & Ta-Feng dataset. \\
\hline Schaeffer and Sanchez [31] & Linear and Radial SVM & $\begin{array}{l}\text { Client-transaction record of a Mexican } \\
\text { parcel delivery company. }\end{array}$ \\
\hline Khalili-Damghani et al. [32] & k-means, IF-THEN rules & $\begin{array}{l}\text { Real-life dataset from insurance company } \\
\text { of Iran and a telecom company. }\end{array}$ \\
\hline Park [33] & Hypothesis Testing & $\begin{array}{l}\text { Real-life dataset from Internet } \\
\text { accommodation reservation Service. }\end{array}$ \\
\hline Khade [34] & C4.5 Decision Tree Algorithm & Real-time database systems. \\
\hline Aluri et al. [35] & Hypothesis Testing & Real-time datasets collected. \\
\hline Hallikainen et al. [36] & Hypothesis Testing & $\begin{array}{l}\text { Real-life data collected using } \\
\text { questionnaire. }\end{array}$ \\
\hline Zhao et al. [37] & Hypothesis Testing & $\begin{array}{l}\text { Kaola.com, one of the largest integrated } \\
\text { B2C e-commerce platforms in China. }\end{array}$ \\
\hline Nardi et al. [38] & $\begin{array}{l}\text { Hypothesis Testing, Meta-Analytic } \\
\text { Structural Equation Modeling (MASEM) }\end{array}$ & $\begin{array}{c}\text { Six different electronic databases: Web of } \\
\text { Science, EBSCO, Google Scholar, Scopus, } \\
\text { Emerald, and ScienceDirect. }\end{array}$ \\
\hline Fernández-Rovira et al. [39] & $\begin{array}{c}\text { Review of Literature with the Snowball } \\
\text { Technique }\end{array}$ & Principal scientific databases. \\
\hline Holmlund et al. [40] & Systematic Literature Review & Web of Science. \\
\hline Zhang et al. [41] & Hypothesis Testing & $\begin{array}{l}\text { Real-life dataset from Chinese B2B } \\
\text { market. }\end{array}$ \\
\hline Subramanian and Prabha [42] & $\begin{array}{l}\text { Bagging Homogeneous Feature Selection, } \\
\text { Naïve Bayes }\end{array}$ & UCI data repository. \\
\hline Khodabandehlou and Rahman [43] & RFM Model & Real data from a food store in Iran. \\
\hline Li et al. [44] & $\begin{array}{c}\text { Decision Tree, Naïve Bayes, Cluster } \\
\text { Analysis }\end{array}$ & $\begin{array}{c}\text { Real-time dataset from Adventure Works } \\
\text { DW database of Adventure Works } \\
\text { Company. }\end{array}$ \\
\hline Sabbeh [45] & $\begin{array}{c}\text { Decision Tree (CART), SVM, kNN, } \\
\text { AdaBoost, Random Forest }\end{array}$ & $\begin{array}{l}\text { Churn dataset from telecommunication } \\
\text { company. }\end{array}$ \\
\hline
\end{tabular}

An additional classification of the CRM elements was performed based on the datamining techniques. The research revealed that most research was conducted in customer retention, and classification and association models were the most frequently used ones. Earley [46] discussed different aspects and advantages of CDPs (customer data platforms), an aggregation of data from various sources, to get a clear idea about the customer. Bahrami et al. [47] evaluated the impact of information technology on CRM by developing a framework for the necessary infrastructure. According to them, the result should be a better relationship with the customers, workable advantages, and cost reduction in the current market where CSPs (communication service providers) have very similar service offers; providing a better customer experience is a significant priority. In their work, 
Spiess et al. [48] investigated different ways of implementing big data to improve customer experience. The authors mainly concentrated on the technology from Alcatel-Lucent and Bell Labs for improving business performances. According to their statement, AlcatelLucent provides a proper structural linkage between the customer and CSP life cycle and the tool, improving net promoter score and higher customer value.

\subsection{Business-Specific CRM Applications}

The banking sector is a data-intensive subject due to its massive number of customers, which requires better strategic management. This makes it a desirable area for different research work. Olaniyan et al. [49] addressed the current problem of achieving customer satisfaction being faced by the Nigerian Banking industry. According to the authors, qualitative research was performed to identify the purpose of customer satisfaction. As stated by the authors, the data were exported to WEKA and then analyzed. Again, Hassani et al. [50] collected and analyzed the data sources, research focus, technologies being used, and data analytical tools, giving a better understanding of DM's application in the banking sector. Iriqat and Daqar [51] determined the role of CRM on customer satisfaction in the banking sector of Palestine. The data collected showed that the two predictors-service quality and CRM system integration-explained $64.2 \% \mathrm{v}$ of the variance showing a positive impact on customer satisfaction. In another research, Ghalenoonie and Sarvestani [52] demonstrated the efficiency of properly collected human resources through a case study on private banks of Shiraz city. The obtained data were analyzed to prioritize human factors in CRM. According to the findings, the view, understanding, and self-recognition are the elements of human resources that have the most positive impact on CRM. Ennew and Binks [53] worked on customer retention in the bank and other small businesses in the UK. They focused on the relationship between service quality and customer relationships and the impact of customer loyalty on retention. Their results show a positive effect on retention and loyalty.

Online marketing is a significant business domain in today's world, opening it up as a research hotspot for researchers. Chiang [54], concentrated on gathering customer knowledge by using a data-driven CRM system of the travel industry of Taiwan. According to the result, air travelers can be partitioned into eight markets using the proposed model. AHP can be used to rank the markets, and the customer value equation can be used to estimate the customers' values. Ballestar et al. [55] presented a customer segmentation of a cashback website depending on the criteria of their commercial activity and website's social network activity. According to this study, the customer's behavior and commercial activity on the website are determined by its role on the social network. Customer segmentation shows their profitability and seniority, and the findings explain their behavior in e-commerce and the importance of using customized retention strategies.

The retail sector is one of the most significant marketing sectors and contains customers all around the globe. Hence it is necessary to analyze the data available for better business performance. Gilboa et al. [56] interviewed owners of small businesses and customers to identify that communication and personal care help gain customers' trust and commitment. Amendola et al. [57] accepted the viewpoint of systems thinking and service logic in their research work and attempted at a twofold aim where it provides the perspective of both the researchers and customers in the fashion industry. According to the work findings, three of the four assumptions cannot be rejected, contributing to the existing knowledge of management in the fashion industry. The lack of big data systems and CRM inclusion in the Pakistan retail sector has led Mahesar et al. [58] to explore the area in their work. In this study, the authors investigated the positive effects of analytical CRM in the retail stores for which they referred to both primary and secondary data. According to their result, the integration improved sales, helped to deal with the data, and diversified business. Bradlow et al. [59] explored the rising potentials of applying big data in retailing based on five data scopes: customer data, location, time, product, and channel. They also discussed issues related to statistical analysis, Bayesian analysis, and predictive analysis in retailing. 
The authors addressed the privacy issues that may arise due to the big data application in retail.

Retailing being India's most significant industry contributes to $10 \%$ of the country's GDP and $8 \%$ of the employment. Mathur and Samma [60] studied the retail market of Udaipur. According to the result acquired by customer loyalty, it is prominent in the industry considering consumers change preferences very frequently. Milovic [61], discussed the different industries CRM is used in due to the customer being the center of the business. This paper discussed the different aspects of CRM that are evaluated in the large and small companies such as customer loyalty, services, behavior, need, retention, etc. Koster [62] addressed the challenges in the distribution strategies faced by the retailer for their internet customers. The variables considered in this research were estimated delivery time, selection of assortment, type of retailer, and orders. According to their results, distribution channels should be integrated into the existing operation.

CRM in higher education is an area that is hardly explored from a research aspect but has high potential. Badwan et al. [63] looked into the benefits of electronic CRM in a higher education institute when taken from students' perspective. They used different statistical tools to analyze the data and test the hypotheses. The findings show that adopting electronic customer relationship management helps with increased performance and better management and improves relationships with the existing and potential students.

The service industry includes many business sectors, among which the telecommunication industry constitutes a significant part, which is the topic of detailed discussion in the next section. Some other sectors of the service industry that demand our attending for research are the hospitality industry, broadband service provider, etc. Schilke and Wirtz [64] developed a model in their work to help the consumers' acceptance of the service bundles in a broadband triple play. They divided the model into four general construct types - usefulness, service characteristics, behavioral intention, and attitude-and derived twelve hypotheses that were tested empirically. Kandampully et al. [65] reviewed customer loyalty in the hospitality industry due to the drastic changes in the marketplaces. They used a conceptual model to build a better framework to understand customer loyalty and customers' developing role. As per the authors' advice, companies should invest in a more emotionally engaging band ambassador and focus more on customer and employee engagement, brand citizenship, and so on.

In hotel management, the customers get influenced by hospitality management to a vast extent. That is why the need to achieve customer satisfaction is also very high. In their work, Nemeschansky et al. [66] developed a customer-driven menu analysis (CDMA) model to analyze the profit of a restaurant using cost management and experience accounting. The four phases in their CDMA model were tested in a restaurant in Auckland, New Zealand. Their model can visualize the price structure depending on customers' opinions to make an improved financial decision for better performance. The lack of existing research works in hospitality management by applying different significant data methods on the customer profiles encouraged Talón-Ballestero et al. [67] to apply big data on the client data for proportion testing. They found high consistency among repetitive travelers without children, with the most similarities among German and British travelers and the main differences with Spanish travelers being age and stay duration. Amoako et al. [68] tried to show the impact of CRM on customer loyalty in the hotel industry. According to their results, $46.3 \%$ were females, and the remaining $53.3 \%$ were males; $40 \%$ became aware of the hotel through newspaper and 30\% through word of mouth; $80 \%$ were ready to refer the hotel to other people whereas $90 \%$ were satisfied with the services of the hotel. Most of the customers agreed to come back to the hotel, which confirmed their loyalty. Sim et al. [69] concentrated their work on the effects of customer satisfaction and customer retention in the hotel industry and how these two factors of CRM impact each other. They also considered the influence of genders and added values in achieving customer satisfaction and retention. According to their results, customer retention depends on customer satisfaction, and the added value is positively affected. Syaqirah and Fuizurrahman [70] 
researched customer retention in the hotel industry in their paper, focusing on a three-star hotel in Malaysia. They used room service quality and customers' consumption emotion, followed by customer satisfaction. This helped them determine whether the customer would choose the same service for their next stay. This would help in strategizing the room service quality.

In the healthcare system, when taken into consideration from a business perspective, the patients are the customers, and their satisfaction is achieved from the curing of the diseases, which requires a massive data generation that requires proper analysis. Khedr et al. [71] proposed a framework for including BI in the healthcare system consisting of six tiers: data source; extract, transform, and load (ETL); data storage; analytics; optimization; and presentation tier. Yaghoubi et al. [72] researched the connection between CKM (customer knowledge management) and CRM in the healthcare system. They also used SPSS and Amos software for this research work. Table 3 discusses the techniques and datasets used in each of the articles reviewed in this section.

Table 3. Techniques and datasets used in business-specific articles.

\begin{tabular}{|c|c|c|}
\hline Reference & Techniques Used (IT-Based) & Dataset Used \\
\hline Olaniyan et al. [49] & $\begin{array}{c}\text { Hypothesis Testing, Logistic Regression, } \\
\text { Support Vector Machine (SVM), Artificial } \\
\text { Neural Network (ANN) }\end{array}$ & Financial report 2017 for WEMA bank. \\
\hline Gilboa et al. [56] & $\begin{array}{l}\text { Hypothesis Testing (Grounded Theory } \\
\text { Approach) }\end{array}$ & $\begin{array}{l}\text { Questionnaire data from small business } \\
\text { owner and customers. }\end{array}$ \\
\hline Hassani et al. [50] & Clustering and Classification Analysis & Existing research work in banking. \\
\hline Ballestar et al. [55] & Cluster Analysis & $\begin{array}{l}\text { Data from cashback websites of } \\
\text { continental Europe. }\end{array}$ \\
\hline Ballestero et al. [67] & Hypothesis Testing & Client data in CRM system. \\
\hline Amendole et al. [57] & Hypothesis Testing & Customer survey from Italian stores. \\
\hline Khedr et al. [71] & Clustering and Classification Techniques & $\begin{array}{l}\text { Patient records from the healthcare } \\
\text { system. }\end{array}$ \\
\hline Badwan et al. [63] & Hypothesis Testing & $\begin{array}{l}\text { Student data from Al Quds Open } \\
\text { University in Palestine. }\end{array}$ \\
\hline Mahesar et al. [58] & Regression Analysis & $\begin{array}{c}\text { Survey data from forty-eight employees } \\
\text { of Hyperstar \& Metro. }\end{array}$ \\
\hline Yaghoubi et al. [72] & Factor Analysis & $\begin{array}{l}\text { Survey data from a military hospital in } \\
\text { Tehran. }\end{array}$ \\
\hline Bradlow et al. [59] & Bayesian Analysis & Dataset from retail chain in US. \\
\hline Ghalenooie and Sarvestani [52] & Hypothesis Testing & Survey data from private banks in Shiraz. \\
\hline Schilke and Wirtz [64] & Hypothesis Testing & $\begin{array}{l}\text { Student survey data from three German } \\
\text { universities. }\end{array}$ \\
\hline Koster [62] & Hypothesis Testing & Survey data from online retailers. \\
\hline Sim et al. [69] & $\begin{array}{l}\text { Structural Equation Modeling and Factor } \\
\text { Analysis }\end{array}$ & $\begin{array}{l}\text { Survey data of hotel customers in the San } \\
\text { Francisco Bay Area. }\end{array}$ \\
\hline Syaqirah and Fuizurrahman [70] & Hypothesis Testing & $\begin{array}{l}\text { Survey data from three-star hotel's } \\
\text { customer in Malaysia. }\end{array}$ \\
\hline Ennew and Binks [53] & Logit Analysis (Statistical Analysis) & $\begin{array}{l}\text { Survey data from the Forum of Private } \\
\text { Business in spring-summer } 1992 .\end{array}$ \\
\hline Dursun and Caber [73] & RFM Analysis & $\begin{array}{l}\text { Real-life dataset from three five-star } \\
\text { hotels of Turkey. }\end{array}$ \\
\hline
\end{tabular}


Table 3. Cont.

\begin{tabular}{|c|c|c|}
\hline Reference & Techniques Used (IT-Based) & Dataset Used \\
\hline Tehrani and Ahrens [74] & Logistic Regression & $\begin{array}{l}\text { Real-life survey data from apparel retailer } \\
\text { from Germany. }\end{array}$ \\
\hline Gera et al. [75] & Hypothesis Testing & $\begin{array}{l}\text { Real-life dataset from life insurance } \\
\text { company from India. }\end{array}$ \\
\hline Pizam et al. [76] & Statistical Analysis & $\begin{array}{l}\text { Existing works on hospitality } \\
\text { management. }\end{array}$ \\
\hline Sano et al. [77] & K-Medoids & $\begin{array}{l}\text { Real-life dataset from groceries in Kanto } \\
\text { area of Japan. }\end{array}$ \\
\hline Diaz et al. [78] & Clustering Analysis & $\begin{array}{l}\text { Real-life dataset from cinema complex of } \\
\text { Spain. }\end{array}$ \\
\hline Brito et al. [79] & K-Medoids and CN2-SD & $\begin{array}{l}\text { Real-life dataset from bivolino.com, a } \\
\text { manufacturer of custom-made shirts. }\end{array}$ \\
\hline Chou et al. [80] & Structural Equation Modeling & $\begin{array}{l}\text { Real-life dataset of consumers from } \\
\text { Taiwan. }\end{array}$ \\
\hline Koehn et al. [81] & Recurrent Neural Network & $\begin{array}{l}\text { Real-world dataset of online shop } \\
\text { focused on fashion items. }\end{array}$ \\
\hline Park et al. [82] & $\begin{array}{l}\text { Linguistic Inquiry and Word Count } \\
\text { (LIWC) }\end{array}$ & $\begin{array}{l}\text { Customer behavioral data collected } \\
\text { through online hotel reservation service } \\
\text { in Seoul, South Korea. }\end{array}$ \\
\hline Appiah et al. [83] & Grounded Theory & $\begin{array}{l}\text { Interview data of smartphone consumers } \\
\text { in UK. }\end{array}$ \\
\hline Adekunle and Ejechi [84] & Hypothesis testing & $\begin{array}{c}\text { Real-life dataset of smartphone users of } \\
\text { Nigerian. }\end{array}$ \\
\hline Kim et al. [85] & Long short-term memory (LSTM) & Real-life dataset of smartphone users. \\
\hline Baashar et al. [86] & Research questions & Existing research works. \\
\hline Garg et al. [87] & Hypothesis testing & $\begin{array}{l}\text { Real-life data collected through } \\
\text { telephone. }\end{array}$ \\
\hline Ying et al. [88] & Statistical software & $\begin{array}{l}\text { Real-life data from the retail sector in } \\
\text { Singapore. }\end{array}$ \\
\hline Li et al. [89] & RFM, Clustering, Decision Tree & $\begin{array}{l}\text { Real-life patient data from outpatient } \\
\text { department. }\end{array}$ \\
\hline
\end{tabular}

\subsection{CRM Analytics in Telecommunication Industry}

Customer churn is the number of customers leaving the company, and managing that is one of the keys to customer retention in this competitive market. Amin et al. [90] showed an approach to customer churn prediction, which works on the concept of classifier's certainty estimation using distance factor. Different state-of-the-art evaluation measures were applied to show that the classifier's certainty profoundly influences the distance factor, and depending on the distance factor's value, the classifier showed higher accuracy for higher costs. Amin et al. [91] In another study, the author worked on crosscompany churn prediction by devising and presenting a model based on different data transformation methods.

Customer retention is a significant aspect in today's business world since the telecom market has reached its maturity peak. The number of new incoming customers is much lower. Kim et al. [92] addressed the following research gap: the lack of work done in the area of customer welfare and bundle subscription, based on pros and cons that lead to the customer subscription, subscription switching cost, and customer retention. They concluded that switching cost is usually higher for subscribers than stand-alone users, and bundle subscription is influenced by lock-in, performance, and economic benefits. Lee et al. [93] 
estimated the interest caused by the extra services provided by B2B in South Korea and the cost estimation of switching telecom service providers. This research led them to conclude that reducing service fees for extra services and exploiting market share would help gain revenue. Ammari and Bilgihan [94] offered a framework that investigates the impact of customer satisfaction and loyalty on customer retention. According to their result, the factor of distributive justice regulates the connection between satisfaction and loyalty, which are the critical factors in customer retention. Mohammed [95] discovered the relationship marketing approaches practiced by the Indian telecom sector at Airtel and the Iraqi telecom sector at Zain. The study revealed that even though Airtel is quite ahead of Zain, the third-largest telecom service globally, the customer's obligation to Zain is much higher, and the customer churn rate is lower than Airtel. In their work, Joshi [96] provided a detailed overview of the current status of the Indian telecom sector, the issues and challenges, and the emerging trends. They divided their review into three phases. The first phase was the structural status of the Indian telecom market in comparison to the global scenario. The second phase discussed the existing work on CRM in telecommunication and a proposition of a conceptual framework. The final stage covered the issues and challenges of the Indian telecom market.

Customer satisfaction is a measurement factor used to determine whether the product or services meet the customers' expectations. Valentim et al. [97] aimed to propose a CRM optimization system using business intelligence (BI) targeted toward the telecommunication sector. In the first phase of their work, they carried out a literature survey strictly on the Scopus and Web of Science databases for the area's available tasks. In their second phase, new concepts were added to the current work, and finally, in the third phase, the newly proposed method was applied in a Brazilian telecom company. Shao et al. [98], in their study on the performance of the services of the telecommunication industry, broke down MTFPI into three aspects, such as technical change represented as innovation, real efficiency changes as catch-up, and scale efficiency change as demand fluctuation. Their results conclude that telecommunication service industries present a more substantial productivity growth due to their high acceptance of technological advances. Gerpott et al. [99] focused on the correlation between MI (mobile Internet) usage and MV (mobile voice) calling pattern. The findings show a balanced relationship between MV and MI usage. Those who send few SMS, are on the younger side, are of foreign nationality, use a smartphone, and have a tariff tenure of a more extended period benefit most from this relationship. Jose et al. [100] tried to identify the key factors influencing the telecom contact center's performance, which plays a vital role in gaining customer satisfaction. The authors conducted a case study on implementing big data analytics on the inbound and outbound telecom contact centers. According to their results, despite having multiple challenges in implementing big data, its scopes are unparalleled. Katona et al. [101] showed the extent of the CRM capabilities in telecommunication companies compared to other companies in the utility market. This entire study revealed the three chosen and remarkable skills associated with the CRM category customer interaction: channel capacity management, channel integration, and customer information availability. According to their research, the telecommunication market's CRM capabilities are much ahead of the utility market. Camilovic [102] surveyed the different data-mining applications used for CRM in telecommunications. While providing data-mining applications, this research also discussed the causes behind these applications and the kinds of data to be mined.

Customer loyalty is a factor that needs to be achieved to avoid customer churn, which is generally directly dependent on the achievement of customer satisfaction. Belwal and Amireh [103] worked on the Omani telecommunication sector in their paper to assess the quality of service of two major Omani telecom companies: Omantel and Ooredoo. This was applied to the attitudinal loyalty of customers to test how the five SERVQUAL dimensions influence them. The result shows a positive influence of reliability and assurance dimension. They concluded that focusing on customer reliability and assurance would gain the companies' higher profit and loyalty. Tong et al. [104] discussed an approach to increase 
customer loyalty by using net promoter score (NPS) data mining. They tried to find the reasons for customer loyalty and to conclude the effect of the customer group aspect on the connection between NPS and financial performance. Ragel et al. [105] examined the potential of relational bonds on customer loyalty with the conciliation of customer satisfaction among mobile telecommunication service providers. The author aimed to detect how customer satisfaction and reliability are influenced by the relationship's level, relationship, and impact. It was concluded that creation, reinforcement, and customer loyalty could be made possible by developing the relationship between the customers and service providers. Dubey et al. [106] showed the positive impact of service quality on customer loyalty and customer relationship management in the Indian telecom sector. Here the authors took five antecedents of service quality, viz. empathy, assurance, responsiveness, tangibility, and reliability. The result states that service quality has a significant and positive impact on customer relationship management and customer loyalty. Haridasan et al. [107] investigated the effectiveness of mobile service provider on customer loyalty. They explained how the two loyalty indices are affected by CRM. Kim et al. [108] examined the impact of "customer satisfaction" and "switching barrier" on "customer loyalty." This paper also analyzed the alternation effect of switching barriers on customer satisfaction and customer loyalty. According to the author, the study's primary purpose was to examine the business strategies used by the Korean telecommunication market. Amin et al. [109] tried to identify the causal factors of customer loyalty in Malaysia's telecommunication providers. The result shows trust, switching cost, service quality, and corporate image influence customer loyalty. Service quality remained the most vital factor in influencing loyalty.

Customer segmentation is the process of dividing customers into groups to provide more personalized services. Zhang et al. [110] proposed a three-dimensional model of customer segmentation from the customer behavior perspective. In this work, the customer segmentation model was based on the business experience whose nationality was verified by factor analysis. Based on these customer characteristics, marketing strategies are made. Nagarajan et al. [111] aimed to design a CPU-effective algorithm CIMTEL to discover closed frequent calling forms in a telecom database. According to the authors, this algorithm exceeds the previous "COLTEL," "CHARM," and "EXPEDITE" algorithms by order of two for a worst-case situation. They stated that CIMTEL can be adopted to apply any association rule to obtain knowledge to control any "fraud detection," "network fault recovery," etc. Weiss [112] provided a detailed description of the types of data available in the telecommunication industry and what purpose they serve if analyzed. Multiple data-mining applications were described in the paper, and when taken together, they can be used to identify telecommunication fraud, improve marketing effectiveness, and identify network faults. Their work also showed various vital issues that dampen the ability to mine data. Arumawadu et al. [113] proposed a modified k-means clustering method to calculate the customers' profit in the Sri Lankan telecommunication industry. Bascacov et al. [114] analyzed the usage of data-mining techniques for calling pattern recognition of the employees and its influence on the business. Again, Routray et al. [115] used a modified version of various pattern growth approaches for pattern recognition on the telecom dataset. Hwang et al. [116] designed a customer lifetime value model considering previous profit, potential profit, churn probability, and another framework for the analysis of customer value and segmentation. Table 4 discusses the techniques and datasets used in each of the articles reviewed in this section. 
Table 4. Techniques and datasets used in article of telecom industry.

\begin{tabular}{|c|c|c|}
\hline Reference & Techniques Used (IT-Based) & Dataset Used \\
\hline Amin et al. [90] & Naïve Bayes & $\begin{array}{l}\text { Publicly available dataset on } \\
\text { telecommunication industry. }\end{array}$ \\
\hline Amin et al. [91] & $\begin{array}{c}\text { Baseline Classifiers (Naïve Bayes, } \\
\text { k-Nearest Neighbor (KNN), Gradient } \\
\text { Boosted Tree (GBT), Single Rule } \\
\text { Induction (SRI), Deep Learning Neural } \\
\text { Network (DP) }\end{array}$ & $\begin{array}{l}\text { Publicly available dataset on } \\
\text { telecommunication industry. }\end{array}$ \\
\hline Kim et al. [92] & Statistical Analysis & Real-life data from Korean company. \\
\hline Lee et al. [93] & Conjoint Analysis & $\begin{array}{l}\text { Real-life survey data from South Korean } \\
\text { telecom. }\end{array}$ \\
\hline Belwal and Amireh [103] & $\begin{array}{l}\text { Partial-Least-Square-Based Structural } \\
\text { Equation Modeling }\end{array}$ & Survey data from Omani telecom industry. \\
\hline Tong et al. [104] & $\begin{array}{l}\text { Information Gain on Decision Tree Model } \\
\text { and k-means Clustering }\end{array}$ & $\begin{array}{l}\text { Survey data from customers of telecom } \\
\text { industry. }\end{array}$ \\
\hline Jose et al. [100] & $\begin{array}{c}\text { Principle Component Analysis (PCA), } \\
\text { Factor Analysis, Regression Analysis, and } \\
\text { Cross Tabulation }\end{array}$ & Data from telecom contact center. \\
\hline
\end{tabular}

Output performance of

Shao et al. [98] Data Envelopment Analysis (DEA) telecommunications service industries in 13 Organization of Economic Cooperation and Development countries from 2000 to 2011.

Mobile Internet (MI) usage and mobile voice (MV) calling patterns among residential customers in one-member country of the Arabian Gulf Cooperation

Gerpott et al. [99] Statistical Analysis

\section{Council (GCC).}

Real-world cross-sectional data from a large European telecommunication provider.

Coussement et al. [117]

Logistic Regression Analysis

Correlation and Regression Analysis

Customer data in mobile telecommunication industry in Batticaloa.

Customer survey data from mobile telecom industry in Tunisia.

Ammari and Bilgihan [94] Hypothesis Testing

Bi et al. [118]

Clustering Techniques

Exploratory Factor Analysis, Regression Analysis

Dubey and Srivastava [106] Boosting and Logistic Regression

Neural Network, Statistical Analysis, Decision Tree, Covering Algorithm

Almana et al. [120] J48 and C5.0 of Decision Tree

Kamalraj and Malathi [121]

Zhang et al. [110]

Kohonen Clustering

Rule-based Data-Mining Technique

Nagarajan et al. [111]

Frontier Analysis

Haridasan and Venkatesh [107]

Hypothesis Testing

Katona and Baier [101]

Camilovic [102]
Dataset from China telecom industry.

Customer survey data from Indian telecommunication industry.

Telecommunication company dataset.

Customer data from telecom industry.

Dataset from Orange database.

Consumption data of a telecom enterprise in the region of Liaoning.

Telecommunication database.

Dataset from mobile telecommunication company in Chennai, Tamil Nadu, India.

Dataset from telecom and utility company in Germany.

Dataset from telecommunication industry. 
Table 4. Cont.

\begin{tabular}{|c|c|c|}
\hline Reference & Techniques Used (IT-Based) & Dataset Used \\
\hline Arumawadu et al. [113] & k-means Clustering & $\begin{array}{l}\text { Customer data in telecommunication } \\
\text { industry in Sri Lanka. }\end{array}$ \\
\hline Kim et al. [108] & Hypothesis Testing & $\begin{array}{l}\text { Survey data from mobile } \\
\text { telecommunication company in Korea. }\end{array}$ \\
\hline Bascacov et al. [114] & Clustering Technique & $\begin{array}{l}\text { Call detail record (CDR) from telecom } \\
\text { industry. }\end{array}$ \\
\hline Routray et al. [115] & Association Rule Mining & Data from Indian telecom industry. \\
\hline Hwang et al. [116] & $\begin{array}{c}\text { Logistic Regression, Neural Network, } \\
\text { Decision Tree }\end{array}$ & $\begin{array}{l}\text { Six-month service data of one wireless } \\
\text { communication company in Korea. }\end{array}$ \\
\hline Amin et al. [109] & Regression Analysis & $\begin{array}{l}\text { Customer survey data from } \\
\text { telecommunication users. }\end{array}$ \\
\hline Verhoef [15] & Hypothesis Testing & $\begin{array}{l}\text { Customer survey data collected over } \\
\text { telephone. }\end{array}$ \\
\hline Amin et al. [122] & $\begin{array}{c}\text { Rule-based Decision-making Technique, } \\
\text { Based on Rough Set Theory (RST) }\end{array}$ & $\begin{array}{l}\text { Publicly available dataset of } \\
\text { telecommunication industry. }\end{array}$ \\
\hline Haq [123] & Simple Mathematical Tools & Dataset from Reliance Jio. \\
\hline Caigny et al. [124] & Decision Tree, Logit Leaf Model & Fourteen different datasets. \\
\hline Shouchen et al. [125] & Distance Method by Norm Method & $\begin{array}{l}\text { Dataset from China telecommunication } \\
\text { industry. }\end{array}$ \\
\hline Nkordeh et al. [126] & Literature Survey & $\begin{array}{l}\text { Existing working in Nigerian } \\
\text { telecommunication industry. }\end{array}$ \\
\hline Bibin and Ramanathan [127] & Conjoint Analysis & Survey data of students. \\
\hline Vafeiadis et al. [128] & $\begin{array}{c}\text { Boosting, Artificial Neural Network, } \\
\text { SVM, Decision Tree, Naïve Bayes, } \\
\text { Logistic Regression }\end{array}$ & UCI Machine Learning Repository. \\
\hline Stripling et al. [129] & $\begin{array}{c}\text { Profit Maximizing Logistic Regression, } \\
\text { Genetic Algorithm }\end{array}$ & $\begin{array}{l}\text { Real-life churn dataset from different } \\
\text { telecommunication service providers. }\end{array}$ \\
\hline Choudhari and Potey [130] & $\begin{array}{c}\text { Fuzzy Unordered Rule Induction } \\
\text { Algorithm (FURIA) }\end{array}$ & Telecom churn dataset. \\
\hline Arifin and Samopa [131] & Support Vector Machine (SVM) & $\begin{array}{l}\text { Real-life dataset from an Indonesian } \\
\text { telecommunication company. }\end{array}$ \\
\hline Diaz [132] & $\begin{array}{c}\text { Generalized Structural Equation } \\
\text { Modeling (GSEM), Multinomial Logit }\end{array}$ & Real-life survey data from Peru. \\
\hline Al-Zadjali and Al-Busaidi [133] & Hypothesis Testing & Survey data collected using questionnaire. \\
\hline Jin et al. [134] & Hypothesis Testing & $\begin{array}{l}\text { Major telecommunication operator in } \\
\text { China. }\end{array}$ \\
\hline Ascarza et al. [135] & $\begin{array}{l}\text { Field Experiment and Manual } \\
\text { Calculations }\end{array}$ & $\begin{array}{l}\text { Real-life data from South American } \\
\text { wireless communication company. }\end{array}$ \\
\hline Friesen and Earl [136] & Non-IT-based Technique & $\begin{array}{l}\text { Real-life data collected from graduate and } \\
\text { postgraduate students. }\end{array}$ \\
\hline García-Mariñoso and Suárez [137] & Logit Model & $\begin{array}{l}\text { Real-life survey data collected by Spanish } \\
\text { Markets and Competition Authority. }\end{array}$ \\
\hline Gerpott and Meinert [138] & Regression Analysis & $\begin{array}{l}\text { A dataset of residential users of mobile } \\
\text { communication services. }\end{array}$ \\
\hline Gerpott and Meinert [139] & Hypothesis Testing & $\begin{array}{c}\text { Data obtained from the German subsidiary } \\
\text { of a large multinational MNO. }\end{array}$ \\
\hline
\end{tabular}




\section{Discussion}

IT-based CRM techniques have been dominating the business world consistently, and the continuous upcoming methods have left them fertile for further research. Our survey indicated the growing scope of study in the area, and in that context, we listed some open research problems and future work directions [140].

The most prominent observation made through the review was the dominant use of IT-based techniques over the non-IT-based ones in all the business sectors over the years. Analytical techniques provided results with higher accuracy irrespective of the business sector and type of dataset, making these the obvious options. Using different data analytical techniques has increased over the years, making it a very adaptable and performative research field.

Supervised learning techniques were the most predominant method throughout the review, with classification and regression analysis offering the most efficient results [141-145]. Among different classification techniques that have been used, the most explored ones are the decision tree and Naïve Bayes. This leaves us with many classification techniques that have not been used in this field of work.

Hypothesis testing and structural equation modeling of statistical analysis are the two other most frequently used techniques that showed higher efficiency. SEM has been mostly used in generalized CRM applications, whereas hypothesis testing has been used in different business applications and widespread CRM applications. Table 4 provides a brief idea about the machine learning techniques referred to in this work.

According to our survey, even though determining the customer's pattern is one of the main goals behind applying analytical techniques in CRM, pattern recognition and the usage of rule-mining technologies have not been the most preferred approach. Association rule mining could be applied more in this area for a better pattern detection of the customer behavior, which may lead to getting a better idea of the customers' needs. This can mainly help in online shopping and telecommunication industries so that the right products can be offered to the right customers at the right time.

Over the years, the amount of research in CRM analytics has increased, and these increasing possibilities will open more scopes for future research. Areas such as customer segmentation and customer retention can use more research because other factors such as customer retention, satisfaction, and loyalty are directly or indirectly dependent on them. For mature markets such as the telecom industry, retention of old customers is vital in doing business. Customer segmentation, without it recommending the right product to the right customer at the right time, would be hard [146-148].

Since most of the research has been done using a real-life dataset obtained from individual companies or through direct surveys, the techniques' accuracy and efficiency may vary vastly depending on the kind of dataset they are being applied to. The dataset difference makes this research area much broader and versatile, thus opening many prospects of work. A similar technique can produce different results when applied to a different dataset. Hence, a technique working for a certain business sector's dataset may not work for another business sector. It may vary from company to company and place to place.

Many business sectors remain unexplored and lack sufficient research on its CRM application such as the education system, healthcare system, online marketing, and so on. The students and the patients can be considered customers when taken into account from a business perspective, making these sectors very applicable for service customization. A vital part of the online market analyzes the customer's buying pattern to suggest the right product combinations. Rule-mining techniques can play a major role, as stated previously. In healthcare, the patient's disease determines the course of treatment to be taken, and the socio-economic status can determine the facilities to be recommended. Similarly, in different business sectors, the customers' demographic data can be used to determine the product or service they might opt for [149-152].

Customer churn prediction is one of the significant aspects of research in the telecom industry due to its high market competition and customer segmentation being the lesser- 
explored area in recent times. Churn's prediction helps with getting to know which customer will leave the service provider so that they can try and retain the customer. Hence this field could use research for better prediction techniques. Customer segmentation also helps determine which customer the company should try to retain, and different groups of customers have different demands and needs. Therefore, it requires more research $[153,154]$.

Irrespective of the business sector, customer loyalty is a significant determining factor for customer retention, directly influencing the customer churn factor. More case studies in this area can help increase the business revenue by earning the customers' trust. Customer loyalty is a very important factor in the business sector such as hotel management, online marketing, hospitality management, healthcare, etc.

According to our research, business sectors have become customer-centric. Hence, rather than just making profits, companies need to work on long-term plans to satisfy their customers. Analytical CRM plays a major role in that scenario, and the different perspectives of this area broaden the research spectrum.

\section{Future Course of Action}

The future course of action should include a detailed descriptive analysis of customers' behavioral and demographic data to get a better understanding of customers' needs. This can help with proper customer segmentation so that it is easier to identify the right product or service for the right customer. It can also help with detecting certain behavioral patterns of customers. The first step to achieving this must be studying customers' profiles. The researchers need to understand what the factors that are influencing the customers' behavior are. This must be followed by a thorough understanding of customers' socioeconomic backgrounds that play a pivotal role in their behavioral pattern. From the telecommunication industry perspective, the type of services or tariff plans customers are opting for will vary depending on their location, economic background, age group, gender identity, etc. For example, the services opted by a working adult from a metropolitan city will not be similar to the services opted by a housewife from a rural area. This is why proper customer segmentation is necessary, and it also helps with better personalization of services provided by companies. Researchers need to study the existing techniques that other sector companies are using to study their customers' data.

One of the major challenges faced by the telecommunication industry is customer churn. Thus, to address this issue, the predictive analysis must be performed on the customers' behavioral data to predict if they are going to churn. With customer retention as the target, proper service designing is necessary. A comparative study must be conducted on the existing techniques in the market to determine which technique provides a better result in a particular dataset so that the relationship with their customers can be improved. Another course of action should be directed toward designing a model that will combine both demographic and behavioral data to understand the customers' needs better. This can help detect patterns in customers' behavior from different socio-economic backgrounds, and we can also find out the effects of different demographic features on the behavioral pattern.

A proper market survey is also necessary to comprehend the maturity level of the market. Understanding the competition is required for better decision making. It can also help with getting updated with the current trends so that organizations can stay up-to-date with the market demands. In the telecommunication industry, the competition is very high, and the number of new customers incoming in the market has decreased over the years. For example, the current market survey on the Indian telecommunication industry shows high teledensity in the urban areas and metropolitan cities, which is why customer retention is necessary for these areas. As the rural areas show low teledensity, the scope of new incoming customers is higher. Proper research on the customers' profiles can help with bringing in new customers. 
Analyzing the customers' feedback can provide insightful knowledge on the different problems faced by the customers. Addressing these problems with proper techniques will lead to better business decision making. This feedback collected from different platforms such as call centers, social media, web-portals, and so on can be analyzed using big data analytics or sentiment analysis, ultimately helping achieve customer satisfaction. Incorporating big data analytics and business intelligence in CRM can help in marketing, sales, and customer services, improving business process efficiency, financial values, employee values, customer values, and technical values. Researchers can work with BI and CRM-influenced tools to reach their target of better decision making.

\section{Conclusions}

In this survey, we reviewed articles from 1996 to 2021 related to CRM, CRM analytics, and its applications in different business sectors. This paper discussed the most commonly used techniques in analytical CRM, various business sectors implementing CRM techniques, and different CRM aspects in the telecommunication industry. The most frequently used methods are supervised learning (32\%), hypothesis testing $(30 \%)$, statistical analysis $(17 \%)$, and so on. We concluded that irrespective of the business area, IT-based CRM techniques help with revenue growth, and their flexible nature works well with the customization process. Hypothesis testing has been the most widely used technique irrespective of the business sector. Determining the customer churn rate in the telecommunication industry has been the most targeted research area. Pattern recognition can be explored more by the researchers, and rule-mining techniques could be used for such purposes. We also found a co-dependency of customer loyalty, customer satisfaction, and customer retention. The importance of proper customer segmentation was highlighted throughout the work. The future work direction can be useful for the researchers looking to work in this area.

Author Contributions: Conceptualization, L.S. and H.K.T.; methodology, L.S. and H.K.T.; software, L.S.; validation, H.K.T., A.K.B. and P.B.; formal analysis, L.S. and H.K.T.; investigation, L.S. and H.K.T.; resources, L.S., H.K.T., S.R.N. and A.K.B.; data curation, L.S.; writing-original draft preparation, L.S.; writing-review and editing, L.S. and H.K.T.; visualization, P.B.; supervision, H.K.T., A.K.B. and S.R.N.; project administration, L.S. and H.K.T. All authors have read and agreed to the published version of the manuscript.

Funding: This research received no external funding.

Institutional Review Board Statement: Not applicable.

Informed Consent Statement: Not applicable.

Data Availability Statement: Not applicable.

Conflicts of Interest: The authors declare no conflict of interest.

\section{References}

1. Department of Telecommunication, Ministry of Communications, Government of India. Available online: https://dot.gov.in/ reportsstatistics/annual-report-2018-19-english (accessed on 23 August 2019).

2. Chen, I.J.; Popovich, K. Understanding customer relationship management (CRM). Bus. Process Manag. J. 2003, 9, 672-688. [CrossRef]

3. Reinartz, W.; Krafft, M.; Hoyer, W.D. The customer relationship management process: Its measurement and impact on performance. J. Mark. Res. 2004, 41, 293-305. [CrossRef]

4. Krishna, G.J.; Ravi, V. Evolutionary computing applied to customer relationship management: A survey. Eng. Appl. Artif. Intell. 2016, 56, 30-59. [CrossRef]

5. Kuruganti, S.; Basu, H. Business Analytics: Applications to Consumer Marketing, 1st ed.; McGraw Hill Education: New Delhi, India, 2015.

6. Anshari, M.; Almunawar, M.N.; Lim, S.A.; Al-Mudimigh, A. Customer relationship management and big data enabled: Personalization \& customization of services. Appl. Comput. Inf. 2018, 15, 94-101. [CrossRef]

7. Rababah, K.; Mohd, H.; Ibrahim, H. Customer relationship management (CRM) processes from theory to practice: The preimplementation plan of CRM system. Int. J. e-Educ. e-Bus. e-Manag. e-Learn 2011, 1, $22-27$. 
8. Parvatiyar, A.; Sheth, J.N. Customer relationship management: Emerging practice, process, and discipline. J. Econ. Soc. Res. 2001, 3, 1-34.

9. Khodakarami, F.; Chan, Y.E. Exploring the role of customer relationship management (CRM) systems in customer knowledge creation. Inf. Manag. 2014, 51, 27-42. [CrossRef]

10. Li, Y.; Huang, J.; Song, T. Examining business value of customer relationship management systems: IT usage and two-stage model perspectives. Inf. Manag. 2019, 56, 392-402. [CrossRef]

11. Nam, D.; Lee, J.; Lee, H. Business analytics use in CRM: A nomological net from IT competence to CRM performance. Int. J. Inf. Manag. 2019, 45, 233-245. [CrossRef]

12. Dong, J.Q.; Yang, C.-H. Business value of big data analytics: A systems-theoretic approach and empirical test. Inf. Manag. 2020, 57, 103124. [CrossRef]

13. Fink, L.; Yogev, N.; Even, A. Business intelligence and organizational learning: An empirical investigation of value creation processes. Inf. Manag. 2017, 54, 38-56. [CrossRef]

14. Nyadzayo, M.W.; Khajehzadeh, S. The antecedents of customer loyalty: A moderated mediation model of customer relationship management quality and brand image. J. Retail. Consum. Serv. 2016, 30, 262-270. [CrossRef]

15. Verhoef, P.C. Understanding the effect of customer relationship management efforts on customer retention and customer share development. J. Mark. 2003, 67, 30-45. [CrossRef]

16. Mikalef, P.; Krogstie, J.; Pappas, I.O.; Pavlou, P. Exploring the relationship between big data analytics capability and competitive performance: The mediating roles of dynamic and operational capabilities. Inf. Manag. 2020, 57, 103169. [CrossRef]

17. Shi, X.; Lin, Z.; Liu, J.; Hui, Y.K. Consumer loyalty toward smartphone brands: The determining roles of deliberate inertia and cognitive lock-in. Inf. Manag. 2018, 55, 866-876. [CrossRef]

18. Benitez, J.; Llorens, J.; Braojos, J. How information technology influences opportunity exploration and exploitation firm's capabilities. Inf. Manag. 2018, 55, 508-523. [CrossRef]

19. Pradana, H.A.; Riza, B.S.; Naseer, M.; Soetarno, D.; Mantoro, T. The effect of e-CRM towards service quality and net benefits using structure equation modeling. In Proceedings of the 2017 Second International Conference on Informatics and Computing (ICIC), Jayapura, Indonesia, 2-4 November 2017; pp. 1-6.

20. Navimipour, N.J.; Soltani, Z. The impact of cost, technology acceptance and employees' satisfaction on the effectiveness of the electronic customer relationship management systems. Comput. Hum. Behav. 2016, 55, 1052-1066. [CrossRef]

21. Chen, H.; Zhang, L.; Chu, X.; Yan, B. Smartphone customer segmentation based on the usage pattern. Adv. Eng. Inform. 2019, 42, 101000. [CrossRef]

22. Pröllochs, N.; Feuerriegel, S. Business analytics for strategic management: Identifying and assessing corporate challenges via topic modeling. Inf. Manag. 2020, 57, 103070. [CrossRef]

23. Hu, K.; Li, Z.; Liu, Y.; Cheng, L.; Yang, Q.; Li, Y. A Framework in CRM Customer Lifecycle: Identify Downward Trend and Potential Issues Detection. arXiv 2018, arXiv:1802.08974.

24. Manu, C. Analysis of clustering technique for crm. Int. J. Eng. Manag. Sci. 2012, 3, 402-408.

25. Krishnamoorthi, S.; Mathew, S.K. Business analytics and business value: A comparative case study. Inf. Manag. 2018, 55, 643-666. [CrossRef]

26. Luo, X.G.; Kwong, C.K.; Tang, J.F.; Sun, F.Q. QFD-Based Product Planning With Consumer Choice Analysis. IEEE Trans. Syst. Man Cybern. Syst. 2015, 45, 454-461. [CrossRef]

27. Soltani, Z.; Navimipour, N.J. Customer relationship management mechanisms: A systematic review of the state of the art literature and recommendations for future research. Comput. Hum. Behav. 2016, 61, 667-688. [CrossRef]

28. Ngai, E.; Xiu, L.; Chau, D. Application of data mining techniques in customer relationship management: A literature review and classification. Expert Syst. Appl. 2009, 36, 2592-2602. [CrossRef]

29. Sundararaj, V.; Rejeesh, M.R. A detailed behavioral analysis on consumer and customer changing behavior with respect to social networking sites. J. Retail. Consum. Serv. 2021, 58, 102190. [CrossRef]

30. Salehinejad, H.; Rahnamayan, S. Customer shopping pattern prediction: A recurrent neural network approach. In Proceedings of the 2016 IEEE Symposium Series on Computational Intelligence (SSCI), Athens, Greece, 6-9 December 2016; pp. 1-6. [CrossRef]

31. Schaeffer, S.E.; Sanchez, S.V.R. Forecasting client retention-A machine-learning approach. J. Retail. Consum. Serv. 2020, 52, 101918. [CrossRef]

32. Khalili-Damghani, K.; Abdi, F.; Abolmakarem, S. Hybrid soft computing approach based on clustering, rule mining, and decision tree analysis for customer segmentation problem: Real case of customer-centric industries. Appl. Soft Comput. 2018, 73, 816-828. [CrossRef]

33. Park, E. Motivations for customer revisit behavior in online review comments: Analyzing the role of user experience using big data approaches. J. Retail. Consum. Serv. 2019, 51, 14-18. [CrossRef]

34. Khade, A.A. Performing Customer Behavior Analysis using Big Data Analytics. Procedia Comput. Sci. 2016, 79, 986-992. [CrossRef]

35. Aluri, A.; Price, B.S.; McIntyre, N.H. Using machine learning to cocreate value through dynamic customer engagement in a brand loyalty program. J. Hosp. Tour. Res. 2019, 43, 78-100. [CrossRef]

36. Hallikainen, H.; Savimäki, E.; Laukkanen, T. Fostering B2B sales with customer big data analytics. Ind. Mark. Manag. 2020, 86, 90-98. [CrossRef] 
37. Zhao, Y.; Wen, L.; Feng, X.; Li, R.; Lin, X. How managerial responses to online reviews affect customer satisfaction: An empirical study based on additional reviews. J. Retail. Consum. Serv. 2020, 57, 102205. [CrossRef]

38. Nardi, V.A.M.; Jardim, W.C.; Ladeira, W.J.; Santini, F. A meta-analysis of the relationship between customer participation and brand outcomes. J. Bus. Res. 2020, 117, 450-460. [CrossRef]

39. Fernández-Rovira, C.; Valdés, J.Á.; Molleví, G.; Nicolas-Sans, R. The digital transformation of business. Towards the datafication of the relationship with customers. Technol. Forecast. Soc. Chang. 2021, 162, 120339. [CrossRef]

40. Holmlund, M.; Van Vaerenbergh, Y.; Ciuchita, R.; Ravald, A.; Sarantopoulos, P.; Ordenes, F.V.; Zaki, M. Customer experience management in the age of big data analytics: A strategic framework. J. Bus. Res. 2020, 116, 356-365. [CrossRef]

41. Zhang, C.; Wang, X.; Cui, A.P.; Han, S. Linking big data analytical intelligence to customer relationship management performance. Ind. Mark. Manag. 2020, 91, 483-494. [CrossRef]

42. Subramanian, R.S.; Prabha, D. Customer behavior analysis using Naive Bayes with bagging homogeneous feature selection approach. J. Ambient. Intell. Humaniz. Comput. 2020, 1-12. [CrossRef]

43. Khodabandehlou, S.; Rahman, M.Z. Comparison of supervised machine learning techniques for customer churn prediction based on analysis of customer behavior. J. Syst. Inf. Technol. 2017, 19, 65-93. [CrossRef]

44. Li, J.; Pan, S.; Huang, L.; Zhu, X. A Machine Learning Based Method for Customer Behavior Prediction. Teh. Vjesn. Tech. Gaz. 2019, 26, 1670-1676. [CrossRef]

45. Sabbeh, S.F. Machine-learning techniques for customer retention: A comparative study. Int. J. of Adv. Comput. Sci. Appl. 2018, 9 , 273-281.

46. Earley, S. The Role of a Customer Data Platform. IT Prof. 2018, 20, 69-76. [CrossRef]

47. Bahrami, M.; Ghorbani, M.; Arabzad, S.M. Information Technology (IT) as An Improvement Tool For Customer Relationship Management (CRM). Procedia Soc. Behav. Sci. 2012, 41, 59-64. [CrossRef]

48. Spiess, J.; T'Joens, Y.; Dragnea, R.; Spencer, P.; Philippart, L. Using big data to improve customer experience and business performance. Bell Labs Tech. J. 2014, 18, 3-17. [CrossRef]

49. Olaniyan, O.M.; Ojukwu, E.; Ogude, C. A Frame Work for Customer Relationship Management in Nigerian Banks Using Data Analytics. FUOYE J. Eng. Technol. 2019, 4. [CrossRef]

50. Hassani, H.; Huang, X.; Silva, E. Digitalisation and Big Data Mining in Banking. Big Data Cogn. Comput. 2018, 2, 18. [CrossRef]

51. Iriqat, R.A.; Abu Daqar, M.A.M. The Role of Customer Relationship Management on Enhancing the Customers' Satisfaction in the Banks in Palestine. Mod. Appl. Sci. 2017, 11, 84. [CrossRef]

52. Ghalenooie, M.B.; Sarvestani, H.K. Evaluating Human Factors in Customer Relationship Management Case Study: Private Banks of Shiraz City. Procedia Econ. Financ. 2016, 36, 363-373. [CrossRef]

53. Ennew, C.T.; Binks, M.R. The Impact of Service Quality and Service Characteristics on Customer Retention: Small Businesses and their Banks in the UK1. Br. J. Manag. 1996, 7, 219-230. [CrossRef]

54. Chiang, W.-Y. Establishing high value markets for data-driven customer relationship management systems. Kybernetes 2019, 48, 650-662. [CrossRef]

55. Ballestar, M.T.; Grau-Carles, P.; Sainz, J. Customer segmentation in e-commerce: Applications to the cashback business model. J. Bus. Res. 2018, 88, 407-414. [CrossRef]

56. Gilboa, S.; Seger-Guttmann, T.; Mimran, O. The unique role of relationship marketing in small businesses' customer experience. J. Retail. Consum. Serv. 2019, 51, 152-164. [CrossRef]

57. Amendola, C.; Calabrese, M.; Caputo, F.; Fabrizio, D. Fashion companies and customer satisfaction: A relation mediated by Information and Communication Technologies. J. Retail. Consum. Serv. 2018, 43, 251-257. [CrossRef]

58. Mahesar, H.A.; Chaudhry, N.I.; Tariq, U. Integrating Customer Relationship Management with Big Data Analytics in Retail Stores: A Case of Hyper-Star and Metro. J. Bus. Strateg. 2017, 11, 141-158.

59. Bradlow, E.T.; Gangwar, M.; Kopalle, P.; Voleti, S. The Role of Big Data and Predictive Analytics in Retailing. J. Retail. 2017, 93, 79-95. [CrossRef]

60. Mathur, M.; Samma, S. A Study on Customer Relationship Management Practices in Selected Organised Retail Stores in Udaipur City. Pac. Bus. Rev. 2010, 14, 1-80.

61. Milovic, B. Application of customer relationship management Strategy (CRM) in different business areas. Factal Univ. Ser. Econ. Organ. 2012, 9, 341-354.

62. De Koster, R. Distribution strategies for online retailers. IEEE Trans. Eng. Manag. 2003, 50, 448-457. [CrossRef]

63. Badwan, J.J.; Al Shobaki, M.J.; Naser, S.S.A.; Amuna, Y.M.A. Adopting technology for customer relationship management in higher educational institutions. Int. J. Eng. Inf. Syst. (IJEAIS) 2017, 1, hal-01500365.

64. Schilke, O.; Wirtz, B.W. Consumer acceptance of service bundles: An empirical investigation in the context of broadband triple play. Inf. Manag. 2012, 49, 81-88. [CrossRef]

65. Kandampully, J.; Zhang, T.; Bilgihan, A. Customer loyalty: A review and future directions with a special focus on the hospitality industry. Int. J. Contemp. Hosp. Manag. 2015, 27, 379-414. [CrossRef]

66. Nemeschansky, B.; von der Heidt, T.; Kim, P.B. Customer-driven menu analysis (CDMA): Capturing customer voice in menu management. Int. J. Hosp. Manag. 2020, 91, 102417. [CrossRef] 
67. Talón-Ballestero, P.; González-Serrano, L.; Soguero-Ruiz, C.; Muñoz-Romero, S.; Rojo-Álvarez, J.L. Using big data from Customer Relationship Management information systems to determine the client profile in the hotel sector. Tour. Manag. 2018, 68, 187-197. [CrossRef]

68. Amoako, G.K.; Arthur, E.; Bandoh, C.; Katah, R.K. The impact of effective customer relationship management (CRM) on repurchase: A case study of (Golden Tulip) hotel (Accra-Ghana). Afr. J. Mark. Manag. 2012, 4, 17-29. [CrossRef]

69. Sim, J.; Mak, B.; Jones, D. A Model of Customer Satisfaction and Retention for Hotels. J. Qual. Assur. Hosp. Tour. 2006, 7, 1-23. [CrossRef]

70. Syaqirah, Z.N.; Faizurrahman, Z.P. Managing Customer Retention of Hotel Industry in Malaysia. Procedia Soc. Behav. Sci. 2014, 130, 379-389. [CrossRef]

71. Khedr, A.; Kholeif, S.; Saad, F. An Integrated Business Intelligence Framework for Healthcare Analytics. Int. J. Adv. Res. Comput. Sci. Softw. Eng. 2017, 7, 263-270. [CrossRef]

72. Yaghoubi, M.; Amiri Fini, S.H.; Rahmati-Najarkolaei, F. The Relationship between Customer Knowledge Management (CKM) on Customer Relationship Management (CRM) Tasks in a Military Hospital. J. Mil. Med. 2017, 18, 308-315.

73. Dursun, A.; Caber, M. Using data mining techniques for profiling profitable hotel customers: An application of RFM analysis. Tour. Manag. Perspect. 2016, 18, 153-160. [CrossRef]

74. Tehrani, A.F.; Ahrens, D. Enhanced predictive models for purchasing in the fashion field by using kernel machine regression equipped with ordinal logistic regression. J. Retail. Consum. Serv. 2016, 32, 131-138. [CrossRef]

75. Gera, R.; Mittal, S.; Batra, D.K.; Prasad, B. Evaluating the Effects of Service Quality, Customer Satisfaction, and Service Value on Behavioral Intentions with Life Insurance Customers in India. Int. J. Serv. Sci. Manag. Eng. Technol. 2017, 8, 1-20. [CrossRef]

76. Pizam, A.; Shapoval, V.; Ellis, T. Customer satisfaction and its measurement in hospitality enterprises: A revisit and update. Int. J. Contemp. Hosp. Manag. 2016, 28, 2-35. [CrossRef]

77. Sano, N.; Tsutsui, R.; Yada, K.; Suzuki, T. Clustering of Customer Shopping Paths in Japanese Grocery Stores. Procedia Comput. Sci. 2016, 96, 1314-1322. [CrossRef]

78. Díaz, A.; Gómez, M.; Molina, A.; Santos, J. A segmentation study of cinema consumers based on values and lifestyle. J. Retail. Consum. Serv. 2018, 41, 79-89. [CrossRef]

79. Brito, P.Q.; Soares, C.; Almeida, S.; Monte, A.; Byvoet, M. Customer segmentation in a large database of an online customized fashion business. Robot. Comput. Manuf. 2015, 36, 93-100. [CrossRef]

80. Chou, S.-F.; Horng, J.-S.; Liu, C.-H.S.; Lin, J.-Y. Identifying the critical factors of customer behavior: An integration perspective of marketing strategy and components of attitudes. J. Retail. Consum. Serv. 2020, 55, 102113. [CrossRef]

81. Koehn, D.; Lessmann, S.; Schaal, M. Predicting online shopping behaviour from clickstream data using deep learning. Expert Syst. Appl. 2020, 150, 113342. [CrossRef]

82. Park, E.; Kang, J.; Choi, D.; Han, J. Understanding customers' hotel revisiting behaviour: A sentiment analysis of online feedback reviews. Curr. Issues Tour. 2018, 23, 605-611. [CrossRef]

83. Appiah, D.; Howell, K.E.; Ozuem, W.; Lancaster, G. Building resistance to brand switching during disruptions in a competitive market. J. Retail. Consum. Serv. 2019, 50, 249-257. [CrossRef]

84. Adekunle, S.A.; Ejechi, J.O. Modelling repurchase intention among smartphones users in Nigeria. J. Model. Manag. 2018, 13, 794-814. [CrossRef]

85. Kim, J.; Ji, H.; Oh, S.; Hwang, S.; Park, E.; del Pobil, A.P. A deep hybrid learning model for customer repurchase behavior. J. Retail. Consum. Serv. 2020, 59, 102381. [CrossRef]

86. Baashar, Y.; Alhussian, H.; Patel, A.; Alkawsi, G.; Alzahrani, A.I.; Alfarraj, O.; Hayder, G. Customer relationship management systems (CRMS) in the healthcare environment: A systematic literature review. Comput. Stand. Interfaces 2020, 71, 103442. [CrossRef]

87. Garg, P.; Gupta, B.; Dzever, S.; Sivarajah, U.; Kumar, V. Examining the Relationship between Social Media Analytics Practices and Business Performance in the Indian Retail and IT Industries: The Mediation Role of Customer Engagement. Int. J. Inf. Manag. 2020, 52, 102069. [CrossRef]

88. Ying, S.; Sindakis, S.; Aggarwal, S.; Chen, C.; Su, J. Managing big data in the retail industry of Singapore: Examining the impact on customer satisfaction and organizational performance. Eur. Manag. J. 2020. [CrossRef]

89. Li, M.; Wang, Q.; Shen, Y.; Zhu, T. Customer relationship management analysis of outpatients in a Chinese infectious disease hospital using drug-proportion recency-frequency-monetary model. Int. J. Med Inform. 2021, 147, 104373. [CrossRef] [PubMed]

90. Amin, A.; Al-Obeidat, F.; Shah, B.; Adnan, A.; Loo, J.; Anwar, S. Customer churn prediction in telecommunication industry using data certainty. J. Bus. Res. 2019, 94, 290-301. [CrossRef]

91. Amin, A.; Shah, B.; Khattak, A.M.; Moreira, F.J.L.; Ali, G.; Rocha, A.; Anwar, S. Cross-company customer churn prediction in telecommunication: A comparison of data transformation methods. Int. J. Inf. Manag. 2019, 46, 304-319. [CrossRef]

92. Kim, M.-K.; Park, M.-C.; Lee, D.H.; Park, J.-H. Determinants of subscriptions to communications service bundles and their effects on customer retention in Korea. Telecommun. Policy 2019, 43, 101792. [CrossRef]

93. Lee, H.; Choi, H.; Koo, Y. Lowering customer's switching cost using B2B services for telecommunication companies. Telematics Informatics 2018, 35, 2054-2066. [CrossRef]

94. Bahri-Ammari, N.; Bilgihan, A. The effects of distributive, procedural, and interactional justice on customer retention: An empirical investigation in the mobile telecom industry in Tunisia. J. Retail. Consum. Serv. 2017, 37, 89-100. [CrossRef] 
95. Mohammed, M.F. Customer relationship management (telecommunication industry) comparison between (Airtel) and (Zain). Int. J. Bus. Manag. Invent. 2013, 2, 52-58.

96. Joshi, D.V.; Sharma, R. CRM in Telecommunication Industry: Issues and Challenges in Indian Context. Int. J. Res. Manag. 2015, 2,24 .

97. Valentim, L.C.; Quelhas, O.L.G.; Ludolf, N.V.-E. Proposição de sistemática para implantação de Customer Relationship Management apoiado por Business Intelligence a organizações do setor de telecomunicação. Sistemas Gestão 2019, 14, $232-244$. [CrossRef]

98. Shao, B.B.M.; Lin, W.T.; Tsai, J.Y. An Empirical Study of the Telecommunications Service Industries Using Productivity Decomposition. IEEE Trans. Eng. Manag. 2017, 64, 437-449. [CrossRef]

99. Gerpott, T.J.; May, S.; Nas, G. The impact of mobile Internet on mobile voice usage: A two-level analysis of mobile communications customers in a GCC country. Inf. Manag. 2017, 54, 958-970. [CrossRef]

100. Jose, B.; Ramanan, T.R.; Kumar, S.D.M. Big data provenance and analytics in telecom contact centers. In Proceedings of the TENCON 2017-2017 IEEE Region 10 Conference, Penang, Malaysia, 5-8 November 2017; pp. 1573-1578.

101. Katona, R.; Baier, D. Customer Relationship Management in the Telecommunications and Utilities Markets. In Innovations in Classification, Data Science, and Information Systems; Springer: Berlin/Heidelberg, Germany, 2005; pp. 346-354.

102. Ćamilović, D. Data mining and CRM in telecommunications. Serb. J. Manag. 2008, 3, 61-72.

103. Belwal, R.; Amireh, M. Service quality and attitudinal loyalty: Consumers' perception of two major telecommunication companies in Oman. Arab. Econ. Bus. J. 2018, 13, 197-208. [CrossRef]

104. Tong, L.; Wang, Y.; Wen, F.; Li, X. The research of customer loyalty improvement in telecom industry based on NPS data mining. China Commun. 2017, 14, 260-268. [CrossRef]

105. Newton, S.; Ragel, V.R. The Effectiveness of Relational Bonds on Customer Loyalty Mediated with Customer Satisfaction: Telecommunication Industry, Batticaloa. Asian J. Econ. Bus. Account. 2017, 4, 1-11. [CrossRef]

106. Dubey, A.; Srivastava, A.K. Impact of service quality on customer loyalty-A study on telecom sector in India. IOSR J. Bus. Manag. (IOSR-JBM) 2016, 18, 45-55. [CrossRef]

107. Haridasan, V.; Venkatesh, S. CRM implementation in Indian telecom industry-Evaluating the effectiveness of mobile service providers using data envelopment analysis. Int. J. of Bus. Res. Manag. 2011, 2, 110-127.

108. Kim, M.-K.; Park, M.-C.; Jeong, D.-H. The effects of customer satisfaction and switching barrier on customer loyalty in Korean mobile telecommunication services. Telecommun. Policy 2004, 28, 145-159. [CrossRef]

109. Amin, S.M.; Ahmad, U.N.U.; Hui, L.S. Factors Contributing to Customer Loyalty Towards Telecommunication Service Provider. Procedia Soc. Behav. Sci. 2012, 40, 282-286. [CrossRef]

110. Zhang, T.-J.; Huang, X.-H.; Tang, J.-F.; Luo, X.-G. Case study on cluster analysis of the telecom customers based on consumers' behavior. In Proceedings of the 2011 IEEE 18th International Conference on Industrial Engineering and Engineering Management, Changchun, China, 3-5 September 2011; pp. 1358-1362.

111. Nagarajan, G.; Minu, R.I.; Vedanarayanan, V.; Jebaseelan, S.S.; Vasanth, K. CIMTEL-Mining Algorithm for Big Data in Telecommunication. Int. J. Eng. Technol. (IJET) 2015, 7, 1709-1715.

112. Weiss, G.M. Data mining in telecommunications. In Data Mining and Knowledge Discovery Handbook; Springer: Boston, MA, USA, 2005; pp. 1189-1201.

113. Arumawadu, H.I.; Rathnayaka, R.M.K.T.; Illangarathne, S.K. Mining Profitability of Telecommunication Customers Using K-Means Clustering. J. Data Anal. Inf. Process. 2015, 3, 63-71. [CrossRef]

114. Bascacov, A.; Cernazanu, C.; Marcu, M. Using data mining for mobile communication clustering and characterization. In Proceedings of the 2013 IEEE 8th International Symposium on Applied Computational Intelligence and Informatics (SACI), Timisora, Romania, 23-25 May 2013; pp. 41-46.

115. Routray, S.K.; Mishra, S.; Sahoo, L. Adaptation of Fast Modified Frequent Pattern Growth approach for frequent item sets mining in Telecommunication Industry. Am. J. Eng. Res. (AJER) 2015, 4, 126-133.

116. Hwang, H.; Jung, T.; Suh, E. An LTV model and customer segmentation based on customer value: A case study on the wireless telecommunication industry. Expert Syst. Appl. 2004, 26, 181-188. [CrossRef]

117. Coussement, K.; Lessmann, S.; Verstraeten, G. A comparative analysis of data preparation algorithms for customer churn prediction: A case study in the telecommunication industry. Decis. Support Syst. 2017, 95, 27-36. [CrossRef]

118. Bi, W.; Cai, M.; Liu, M.; Li, G. A Big Data Clustering Algorithm for Mitigating the Risk of Customer Churn. IEEE Trans. Ind. Inform. 2016, 12, 1270-1281. [CrossRef]

119. Lu, N.; Lin, H.; Lu, J.; Zhang, G. A Customer Churn Prediction Model in Telecom Industry Using Boosting. IEEE Trans. Ind. Inform. 2012, 10, 1659-1665. [CrossRef]

120. Almana, A.M.; Aksoy, M.S.; Alzahrani, R. A survey on data mining techniques in customer churn analysis for telecom industry. Int. J. Eng. Res. Appl. 2014, 45, 165-171.

121. Kamalraj, N.; Malathi, A. Applying data mining techniques in telecom churn prediction. Int. J. Adv. Res. Comput. Sci. Softw. Eng. 2013, 3, 363-370.

122. Amin, A.; Anwar, S.; Adnan, A.; Nawaz, M.; Alawfi, K.; Hussain, A.; Huang, K. Customer churn prediction in the telecommunication sector using a rough set approach. Neurocomputing 2017, 237, 242-254. [CrossRef]

123. Haq, N. Impact of Reliance JIO on the Indian telecom industry. Int. J. Eng. Manag. Res. (IJEMR) 2017, 7, $259-263$. 
124. De Caigny, A.; Coussement, K.; De Bock, K.W. A new hybrid classification algorithm for customer churn prediction based on logistic regression and decision trees. Eur. J. Oper. Res. 2018, 269, 760-772. [CrossRef]

125. Shuochen, X.; Lianju, N.; Wenying, Z. Study of matching model between tariff package and user behavior. J. China Univ. Posts Telecommun. 2017, 24, 91-96. [CrossRef]

126. Nkordeh, N.; Bob-Manuel, I.; Olowononi, F. The Nigerian telecommunication industry: Analysis of the first fifteen years of the growths and challenges in the GSM market (2001-2016). In Proceedings of the World Congress on Engineering and Computer Science, San Francisco, CA, USA, 25-27 October 2017.

127. Bibin, P.B.; Ramanathan, H.N. Identifying the Best Mobile Combo Tariff Plan for Professional Students: An Application of Conjoint Analysis. Int. J. Bus. Anal. Intell. 2018, 6, 36.

128. Vafeiadis, T.; Diamantaras, K.; Sarigiannidis, G.; Chatzisavvas, K. A comparison of machine learning techniques for customer churn prediction. Simul. Model. Pr. Theory 2015, 55, 1-9. [CrossRef]

129. Stripling, E.; Broucke, S.V.; Antonio, K.; Baesens, B.; Snoeck, M. Profit maximizing logistic model for customer churn prediction using genetic algorithms. Swarm Evol. Comput. 2018, 40, 116-130. [CrossRef]

130. Choudhari, A.S.; Potey, M. Predictive to Prescriptive Analysis for Customer Churn in Telecom Industry Using Hybrid Data Mining Techniques. In Proceedings of the 2018 Fourth International Conference on Computing Communication Control and Automation (ICCUBEA), Pune, India, 16-18 August 2018; pp. 1-6.

131. Arifin, S.; Samopa, F. Analysis of Churn Rate Significantly Factors in Telecommunication Industry Using Support Vector Machines Method. J. Phys. Conf. Ser. 2018, 1108, 012018. [CrossRef]

132. Díaz, G.R. The influence of satisfaction on customer retention in mobile phone market. J. Retail. Consum. Serv. 2017, 36, 75-85. [CrossRef]

133. Al-Zadjali, M.; Al-Busaidi, K.A. Empowering CRM through business intelligence applications: A study in the telecommunications sector. Int. J. Knowl. Manag. (IJKM) 2018, 14, 68-87. [CrossRef]

134. Jin, H.; Lu, Z.; Huang, L.; Dou, J. Not too much nor too little: Salience bias in mobile plan choices. Telecommun. Policy 2021, 45, 102071. [CrossRef]

135. Ascarza, E.; Iyengar, R.; Schleicher, M. The perils of proactive churn prevention using plan recommendations: Evidence from a field experiment. J. Mark. Res. 2016, 53, 46-60. [CrossRef]

136. Friesen, L.; Earl, P.E. Multipart tariffs and bounded rationality: An experimental analysis of mobile phone plan choices. J. Econ. Behav. Organ. 2015, 116, 239-253. [CrossRef]

137. García-Mariñoso, B.; Suárez, D. Switching mobile operators: Evidence about consumers' behavior from a longitudinal survey. Telecommun. Policy 2019, 43, 426-433. [CrossRef]

138. Gerpott, T.J.; Meinert, P. The impact of mobile Internet usage on mobile voice calling behavior: A two-level analysis of residential mobile communications customers in Germany. Telecommun. Policy 2016, 40, 62-76. [CrossRef]

139. Gerpott, T.J.; Meinert, P. Choosing a wrong mobile communication price plan: An empirical analysis of predictors of the degree of tariff misfit among flat rate subscribers in Germany. Telemat. Inform. 2017, 34, 303-313. [CrossRef]

140. Libai, B.; Bart, Y.; Gensler, S.; Hofacker, C.F.; Kaplan, A.; Kötterheinrich, K.; Kroll, E.B. Brave New World? On AI and the Management of Customer Relationships. J. Interact. Mark. 2020, 51, 44-56. [CrossRef]

141. Mishra, S.; Tripathy, H.K.; Mallick, P.K.; Bhoi, A.K.; Barsocchi, P. EAGA-MLP—An Enhanced and Adaptive Hybrid Classification Model for Diabetes Diagnosis. Sensors 2020, 20, 4036. [CrossRef] [PubMed]

142. Mishra, S.; Mallick, P.; Tripathy, H.; Bhoi, A.; González-Briones, A. Performance Evaluation of a Proposed Machine Learning Model for Chronic Disease Datasets Using an Integrated Attribute Evaluator and an Improved Decision Tree Classifier. Appl. Sci. 2020, 10, 8137. [CrossRef]

143. Mishra, S.; Mallick, P.K.; Jena, L.; Chae, G.-S. Optimization of Skewed Data Using Sampling-Based Preprocessing Approach. Front. Public Health 2020, 8, 274. [CrossRef] [PubMed]

144. Mishra, S.; Tripathy, H.K.; Mishra, B.K. Implementation of biologically motivated optimisation approach for tumour categorisation. Int. J. Comput. Aided Eng. Technol. 2018, 10, 244. [CrossRef]

145. Mallick, P.K.; Mishra, S.; Chae, G.-S. Digital media news categorization using Bernoulli document model for web content convergence. Pers. Ubiquitous Comput. 2020, 1-16. [CrossRef]

146. Sahoo, S.; Das, M.; Mishra, S.; Suman, S. A Hybrid DTNB Model for Heart Disorders Prediction. In Advances in Electronics, Communication and Computing; Springer: Singapore, 2021; pp. 155-163.

147. Tutica, L.; Vineel, K.S.K.; Mishra, S.; Mishra, M.K.; Suman, S. Invoice Deduction Classification Using LGBM Prediction Model. In Advances in Electronics, Communication and Computing; Springer: Singapore, 2021; pp. 127-137.

148. Mishra, S.; Tadesse, Y.; Dash, A.; Jena, L.; Ranjan, P. Thyroid Disorder Analysis Using Random Forest Classifier. In Intelligent and Cloud Computing; Springer: Singapore, 2021; pp. 385-390.

149. Hossain, A.; Akter, S.; Yanamandram, V. Revisiting customer analytics capability for data-driven retailing. J. Retail. Consum. Serv. 2020, 56, 102187. [CrossRef]

150. Hossain, M.A.; Akter, S.; Yanamandram, V. Why doesn't our value creation payoff: Unpacking customer analytics-driven value creation capability to sustain competitive advantage. J. Bus. Res. 2021, 131, 287-296. [CrossRef]

151. Shamim, S.; Yang, Y.; Zia, N.U.; Shah, M.H. Big data management capabilities in the hospitality sector: Service innovation and customer generated online quality ratings. Comput. Hum. Behav. 2021, 121, 106777. [CrossRef] 
152. Huang, P.Y.; Niu, B.; Pan, S.L. Platform-based customer agility: An integrated framework of information management structure, capability, and culture. Int. J. Inf. Manag. 2021, 59, 102346. [CrossRef]

153. Mishra, S.; Mallick, P.K.; Tripathy, H.K.; Jena, L.; Chae, G.-S. Stacked KNN with hard voting predictive approach to assist hiring process in IT organizations. Int. J. Electr. Eng. Educ. 2021. [CrossRef]

154. Jena, L.; Mishra, S.; Nayak, S.; Ranjan, P.; Mishra, M.K. Variable Optimization in Cervical Cancer Data Using Particle Swarm Optimization. In Advances in Electronics, Communication and Computing; Springer: Singapore, 2021; pp. 147-153. 